\title{
TECTONOPHYSICS
}

ELSEVIER

\section{The Velay dome (French Massif Central): melt generation and granite emplacement during orogenic evolution}

\author{
P. Ledru ${ }^{\mathrm{a}, *}$, G. Courrioux ${ }^{\mathrm{a}}$, C. Dallain ${ }^{\mathrm{b}}$, J.M. Lardeaux $^{\text {c }}$, J.M. Montel $^{\mathrm{d}}$, \\ O. Vanderhaeghe ${ }^{\mathrm{e}}$, G. Vitel ${ }^{\mathrm{f}}$ \\ a Department of Geophysics, BRGM, BP 6009, 45060 Orléans cedex 02, France \\ ${ }^{\mathrm{b}} R$. Castelginest, 81000 Albi, France \\ ${ }^{\mathrm{c}}$ University of Lyon 1, 15-43 bd 11 Novembre, 69621 Villeurbanne, France \\ ${ }^{\mathrm{d}}$ LMTG-UMR 5563, Department of Mineralogy, University Paul Sabatier, 39 Allée Jules Guesde, F-31000 Toulouse, France \\ ${ }^{\mathrm{e}} U M R$ G2R, University of Nancy 1, BP239, 54560 Nancy, France \\ ${ }^{\mathrm{f}}$ University of St Etienne, 23 rue Docteur Michelon, 42023 St. Etienne, France
}

Received 20 June 2001

\begin{abstract}
This paper is a synthesis of available data on the Velay dome that include both small- and large-scale lithologic and structural mapping, strain analysis, isotope geochemistry, geochronology and pressure-temperature estimates. The Velay dome, one of the largest granite-migmatite domes of the Variscan Belt, formed during orogenic collapse at around $300 \mathrm{Ma}$. Its study allows an assessment of the thermal and geodynamic context leading to voluminous crustal anatexis of the Variscan orogenic crust. A first melting stage developed in connection with south-verging thrust zones during the Early Carboniferous, leading to a crustal thickening estimated at $20 \mathrm{~km}$ minimum. The involvement of fertile lithologies and the intrusion of plutons of deep origin contributed to the development of water-saturated melts. The volume of biotite granite extracted from melt during this period was limited. The second phase of melting, corresponded to generalized melting of gneiss achieved by biotite-dehydration melting reactions and accompanied by the generation of cordierite-bearing granites. At this stage, crustal-scale detachment faults were active and partially obliterated the earlier structures. The new structures were progressively tilted to the vertical at the margin of the Velay dome due to the southward and lateral ballooning of the granitic dome. The reconstructed $P, T$ path indicate that the large volume of melt produced was a consequence of a significant increase in temperature at the onset of biotite dehydration melting. At the base of the crust, this melting event is coeval with granulite facies metamorphism associated to underplating of mantle-derived magmas as suggested by the geochemical signature of Late Paleozoic lower crustal xenoliths sampled by Cenozoic volcanoes and with the isotopic signature of the late granitic intrusions. Accordingly, it is proposed that asthenospheric upwelling was responsible for the temperature increase favoring melting of hydrous minerals. (C) 2001 Published by Elsevier Science B.V.
\end{abstract}

Keywords: Variscan belt; Velay dome; Migmatization; Granite; Extension

\footnotetext{
${ }^{*}$ Corresponding author. Tel.: +33-2386-43907; fax: +33-2386-44702.

E-mail addresses: p.ledru@brgm.fr (P. Ledru), g.courrioux@brgm.fr (G. Courrioux), ndallain@aol.com (C. Dallain), Lardeaux@univ-lyon1.fr (J.M. Lardeaux), montel@cict.fr (J.M. Montel), Olivier.vanderhaeghe@g2r.uhp-nancy.fr (O. Vanderhaeghe), vitel@univ-etienne.fr (G. Vitel).
} 


\section{Introduction}

The generation of large granite-migmatite complexes by crustal melting during orogeny is a process still discussed in particular because of the deep, inaccessible location of their production sites (Clemens, 1990; Brown, 1994). Moreover, the development of a partially molten middle crust during collision tectonics implies a major change in the rheology of the thickened crust and largely control its behaviour during orogenic collapse (Vanderhaeghe and Teyssier, 2001). Thus, the Variscan belt which exposes numerous granitic intrusions and large migmatitic complexes is of great interest to study the role of partial melting during orogenic evolution (Brown and Dallmeyer, 1996; Gardien et al., 1997; Vanderhaeghe et al., 1999). The Velay migmatite-granite dome located in the SE Massif Central (Fig. 1) offers a unique opportunity to examine the thermal conditions required for widespread crustal anatexis and the consequences of the presence of the generation of a large volume of partially molten rocks on the evolution of the Variscan orogenic crust.

Previous work in this area provided the following results and models:

- Montel et al. (1992) describe two successive stages of anatexis, first under water-saturated conditions with biotite stable followed by melting under biotite dehydration conditions.

- Burg and Vanderhaeghe (1993) proposed that the amplification of the Velay dome cored by migmatites and granites reflects gravitational instabilities within a partially molten middle crust during late-orogenic extension.

- Lagarde et al. (1994) suggested that the deformation pattern of the Velay dome records southward lateral expansion of the granites below the detachment zone of the Pilat, one of the major normal faults developed during the collapse of the Variscan belt (Malavieille et al., 1990).

- Geochemical and petrological data published by Williamson et al. (1992), Montel et al. (1992) and Barbey et al. (1999) indicate that the Velay dome has followed a clockwise $P-T-$ time evolution overprinted by a thermal peak due to the underplating of mafic magmas.
In this paper, we present a synthesis of available structural, petrologic, geochemical and geochronological data illustrated with new maps of the main granite and migmatite units. The significance of this body of work is discussed in the general context of the Variscan Belt, and in terms of the thermal conditions required to generate large volume of crustal melts as exemplified by the Velay dome.

\section{Tectonic evolution of the Eastern Massif Central}

The French Variscan Belt (Fig. 1) results from collision between Laurussia and Gondwana (Matte, 1986). The Massif Central exposes a section of orogenic crust estimated to be about $20-\mathrm{km}$ thick in its innermost zone, made up of Late Neoproterozoic to Permian terranes transformed during successive metamorphic events (Pin and Peucat, 1986). Contrasts in lithologic, structural and metamorphic evolution between the main gneiss units define three lithotectonic domains separated by major thrust zones (Figs. 1 and 2, Burg and Matte, 1978; Ledru et al., 1994a,b; Chantraine et al., 1996).

The remnants of Early Paleozoic oceanic or marginal basins constitute the protoliths of the Upper Gneiss Unit. Presently in an upper geometric position, this unit contains dismembered basic-ultrabasic complexes at its base overlain by gneisses derived from granites, microgranites, acid and basic volcanics, tuffs and grauwackes. Numerous eclogitic relics are preserved within basic layers marking an Eovariscan stage of lithospheric subduction (450-400 Ma). Structural and radiometric data show these rocks were exhumed from $90 \mathrm{~km}$ at $420-400 \mathrm{Ma}$ to less than 30 $\mathrm{km}$ at 360-380 Ma while subduction was still active (Lardeaux et al., in press).

The north Gondwana continental margin is represented by (a) a Lower Gneiss Unit composed of paraand ortho-derived rocks of Late Neoproterozoic to Early Paleozoic age, and (b) a mainly sedimentary parautochthonous sequence. This margin underwent a general medium-pressure metamorphism attributed to the thrusting of the Upper Gneiss Unit which occurred during Devonian, prior to $350 \mathrm{Ma}$ in the internal zone (Mesovariscan period). In the south (Fig. 2), the Cévennes micaschists are interpreted as the parautochthonous domain. Maximum $P-T$ conditions dur- 


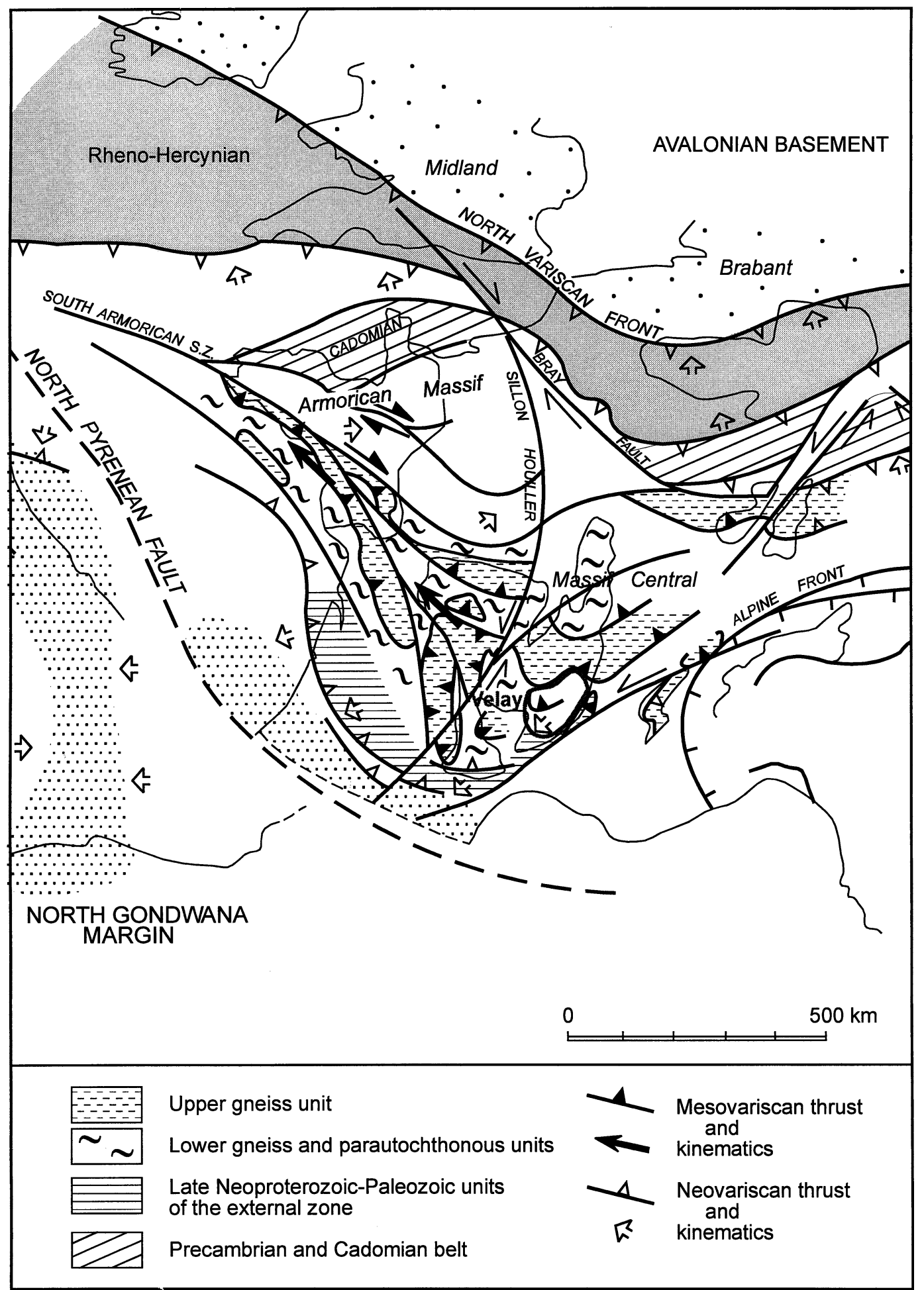

Fig. 1. The Velay dome shown on the scale of the European Variscides (adapted from Autran and Cogné, 1980; Matte, 1986). 


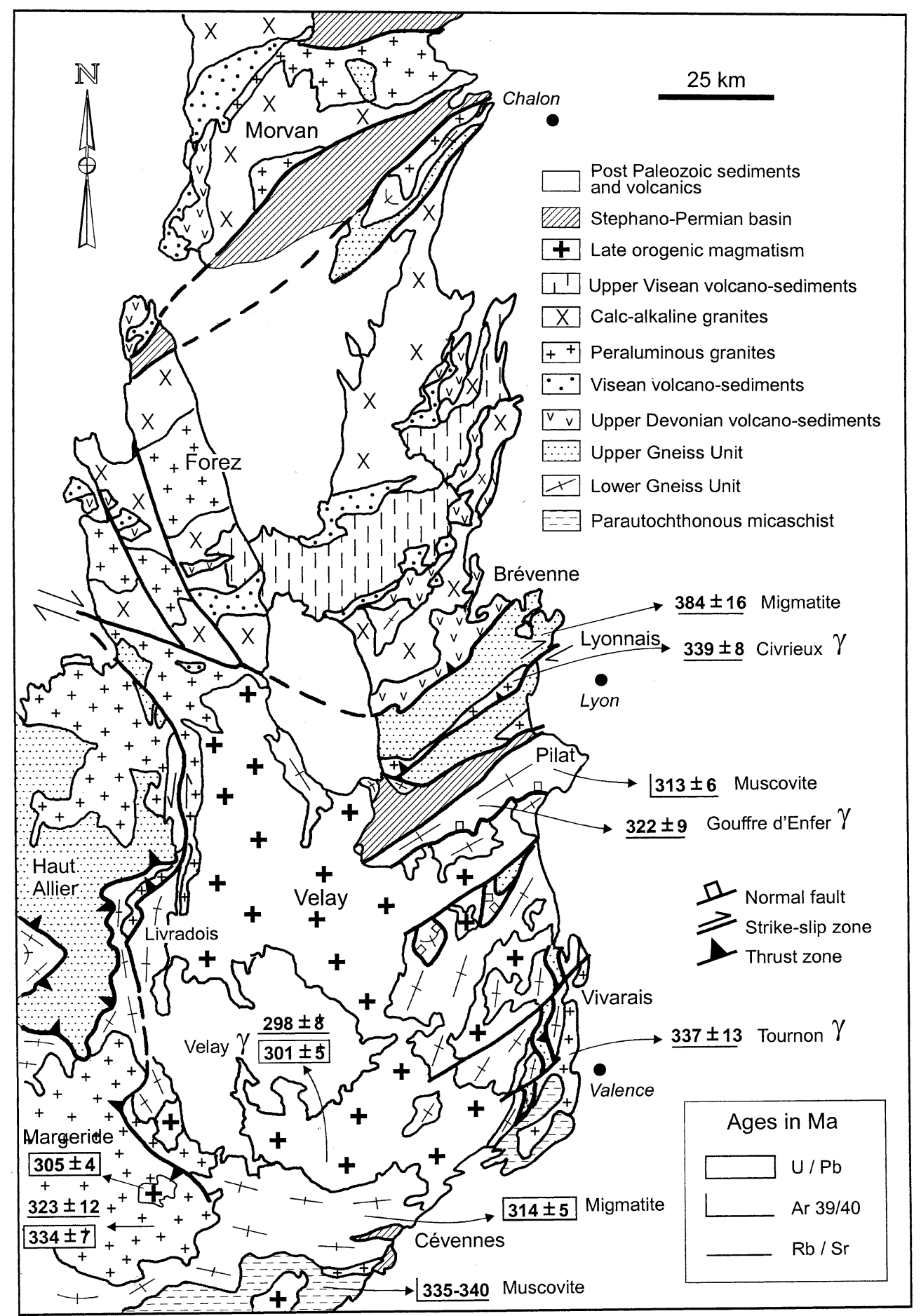

Fig. 2. Simplified geologic map of the eastern margin of the Massif Central and chronological markers (from Chantraine et al., 1996). 
ing the metamorphic evolution are there estimated at $500{ }^{\circ} \mathrm{C}, 5 \mathrm{kbar}$, with the muscovite-chlorite-garnet parageneses being synchronous with southward thrusting and a thickening estimated at about $15 \mathrm{~km}$ (Arnaud and Burg, 1993; Arnaud, 1997). The closure of micas to Ar diffusion has been dated at 335-340 Ma (Ar39/40, Caron et al., 1991).

Finally, the Paleozoic cover of the northern Gondwana continental margin is represented by a complex of nappes exposed in the southern part of the Massif Central, which is progressively involved during Visean in the collision history (Fig. 1). The tectonic evolution of the Eastern Massif Central is thus characterized by a southward migration of tectonic events, from the internal towards the external zone, between 400 and $330 \mathrm{Ma}$ (Table 1). From $330 \mathrm{Ma}$, signs of syncollision extension are recorded, followed by transverse extension from 315 to $290 \mathrm{Ma}$ (Burg et al., 1994). Granites and migmatites are formed during all this evolution. Thus, the emplacement of large peraluminous porphyric granites (Margeride) and potassic monzogranite of calc-alkaline affinity (Forez, Morvan) during Visean is followed by the development of the Velay migmatite-granite dome during Westphalian (Fig. 2). Finally, a granulite facies metamorphism of the base of the crust dated at $300 \pm 20 \mathrm{Ma}(\mathrm{U} / \mathrm{Pb}$, Pin and Vielzeuf, 1983) is attested by the xenoliths brought up by the Tertiary volcanoes of the Velay (Leyreloup, 1973; Dupuy et al., 1977).

\section{Geologic setting of the Velay dome}

The Velay dome (Fig. 2, Plate 1), about $100 \mathrm{~km}$ in diameter, is composed of peraluminous granites (about $70 \%$ ) characterized by abundance of nodular and prismatic cordierite and by enclaves of gneisses $(25 \%)$ and granites $(5 \%)$ of various nature and size (Didier, 1973; Dupraz and Didier, 1988). Three main structural zones are defined: (1) the host rocks intruded by syntectonic granites precursor of the Velay dome; (2) the gneiss-migmatite zone, at the periphery and at the roof of the Velay dome; (3) the cordieritebearing migmatite-granite domain constituting the most evolved pole of the granitisation of the crust. 


\subsection{The host rocks of the Velay dome}

The main lithologic units of the Variscan nappe stack identified in Section 2 appear either at the periphery of the Velay dome or as enclaves within the migmatite-granite core. Rocks attributed to the Upper Gneiss Unit are preserved in the northeastern part of the dome roof (Maclas synform; Gardien and Lardeaux, 1991) and are intruded by migmatites and granites along the northwestern (Haut Allier) and southeastern margins (Alboussière synform) of the Velay dome. Structures and metamorphism are attributed to the mesovariscan thrusting of this unit over the domain comprised between the Monts du Lyonnais and the Cévennes (D1-2 tectonic phase, Table 1). Metamorphic peak conditions are found in the Lyonnais where a coesite-bearing eclogite has been recently discovered in the Monts du Lyonnais, indicating a minimum 28-kbar pressure (Lardeaux et al., in press), while in most eclogites, $P-T$ conditions are estimated at $16-14 \mathrm{kbar}$ and $700-770{ }^{\circ} \mathrm{C}$ (Gardien and Lardeaux, 1991). Anatectic metapelites surrounding the eclogites yield a date of $384 \pm 16 \mathrm{Ma}$, interpreted as a crystallization age $(\mathrm{Rb} / \mathrm{Sr}$ whole rock, Duthou et al, 1994).

The host of the Velay dome is primarily composed of rocks of the Lower Gneiss Unit: (i) metasediments derived from pelites and argilites, (ii) augen orthogneiss (the "Arc de Fix") originating from peraluminous porphyric granite dated at $528 \pm 9 \mathrm{Ma}(\mathrm{Rb}-\mathrm{Sr}$ whole rock, R'Kha Chaham et al., 1990). In the vicinity of the main thrust contact with the Upper Gneiss unit, the main deformation $\mathrm{D}_{1-2}$ (foliation $\mathrm{S}_{1-2}$, lineation $\mathrm{L}_{2}$ ) is related to Mesovariscan thrusting (Table 1). The metamorphic evolution was marked by widespread development of sillimanite-biotite parageneses within the paragneiss and micaschist series, locally with kyanite or staurolite-garnet relic association (Gardien, 1990). However, in the western margin of the Velay dome (Feybesse et al., 1995), a $\mathrm{D}_{3}$ reactivation of this nappe pile is marked by south verging thrust zones and related $\mathrm{S}_{3}-\mathrm{L}_{3}$ fabric (Table 1).

In the south, the Velay migmatite-granite intrudes the parautochthonous domain. The main structures observed are related to Neovariscan thrusting at around $340 \mathrm{Ma}$ and are considered as equivalent to the $\mathrm{D}_{3}$ reactivation of the Mesovarican nappe pile on the western margin of the Velay dome. In the Cév- ennes paragneisses and micaschists, metamorphic conditions increase northward towards the Velay dome contact and reflect an abnormally high geothermal gradient (Weisbrod et al., 1980). Successive biotite-andalusite, andalusite-cordierite and biotitesillimanite parageneses are consistent with the evolution of the Lower Gneiss Unit on the northern and western edges of the dome (Chenevoy and Ravier, 1968; Gardien, 1990).

The Lower Gneiss Unit is affected in the northeastern margin of the dome by the Pilat detachment Fault (Gardien, 1990; Malavieille et al., 1990), extending westward into the Chambles granite, which underwent solid-state deformation consistent with top to the north sense of shear (Roig and Faure, 1995). $\mathrm{NE}-\mathrm{SW}$ foliation and $\mathrm{N}-\mathrm{S}$ trending stretching lineations developed during low-pressure high-temperature metamorphism are related to this deformation $\left(\mathrm{D}_{4 \mathrm{a}}\right.$ tectonic stage, Table 1, Fig. 3$)$.

Large antiforms and synforms of plurikilometric wavelength are parallel to the contact with the Velay dome (Fig. 4). This peripheral folding revealed by the foliation trajectories is attributed to the ballooning of the Velay migmatite-granite dome and the tilting of a flat-lying foliation during final emplacement of the cordierite-bearing granites $\left(\mathrm{D}_{4 \mathrm{~b}}\right.$ tectonic stage, Table 1). It is noted that the sediments of the St Etienne basin are deposited in the hinge of such synform structure (Plate 1).

\subsection{Porphyric granites emplaced at the periphery of the Velay dome}

Homogeneous porphyric granites and leucogranites have intruded the host rocks of the Velay dome (Plate 1). They constitute a quasi continuous belt of laccolith-like plutons stretched along the regional structures and represent a peak in the production of granites in the Eastern French Massif Central. Their emplacement postdates $D_{1-2}$ structures attributed to Mesovariscan thrusting and predates cordierite-bearing granites in which they are found as enclaves (Table 1, Fig. 5a).

Small monzodiorite to monzogabbrodiorite massifs (locally called vaugnerites and high-K magnesian monzodiorite in the rest of the text), with shoshonitic affinities, are associated with these intrusions, presenting distinct or blurred boundaries (Fig. 5b,c). The high- 

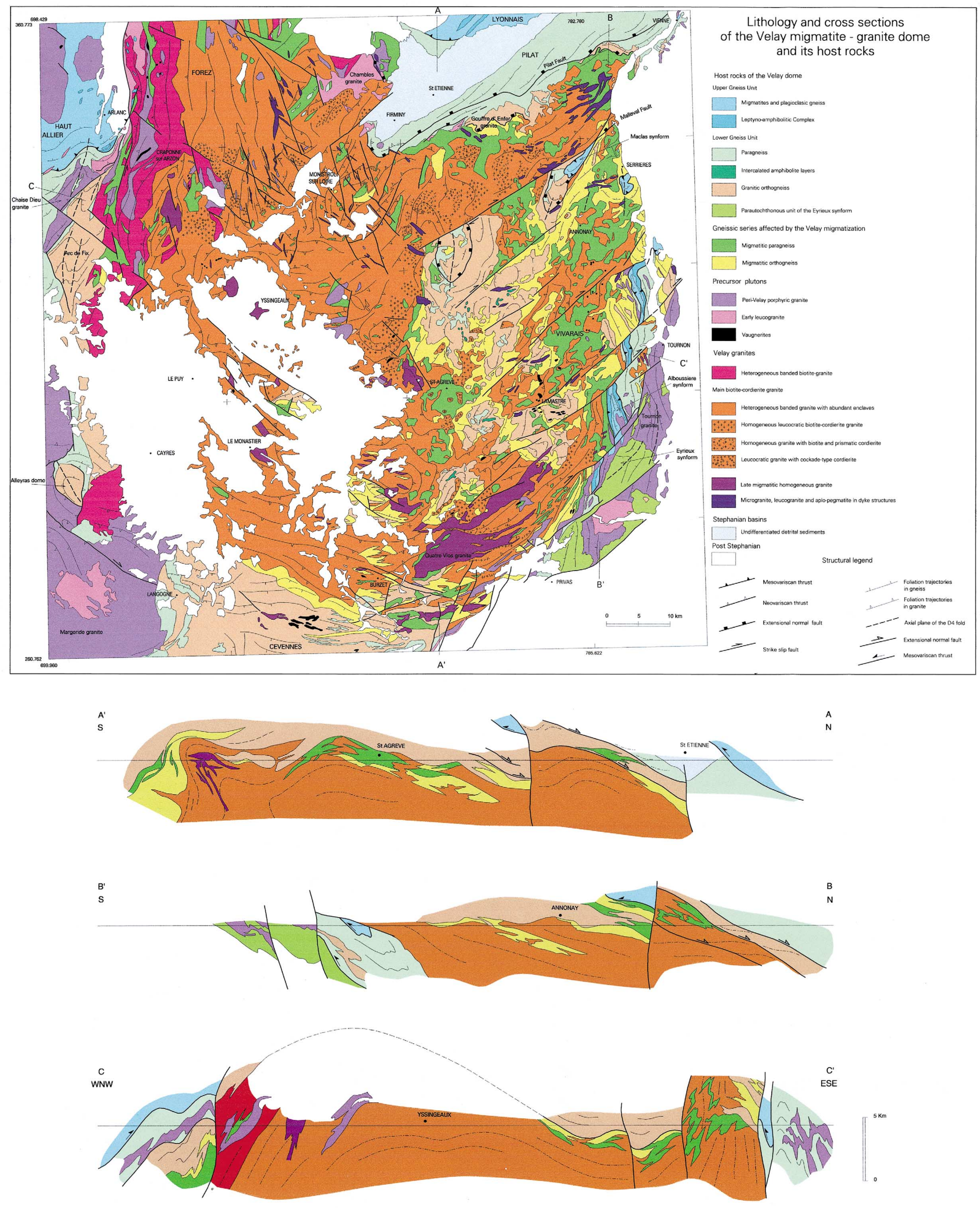


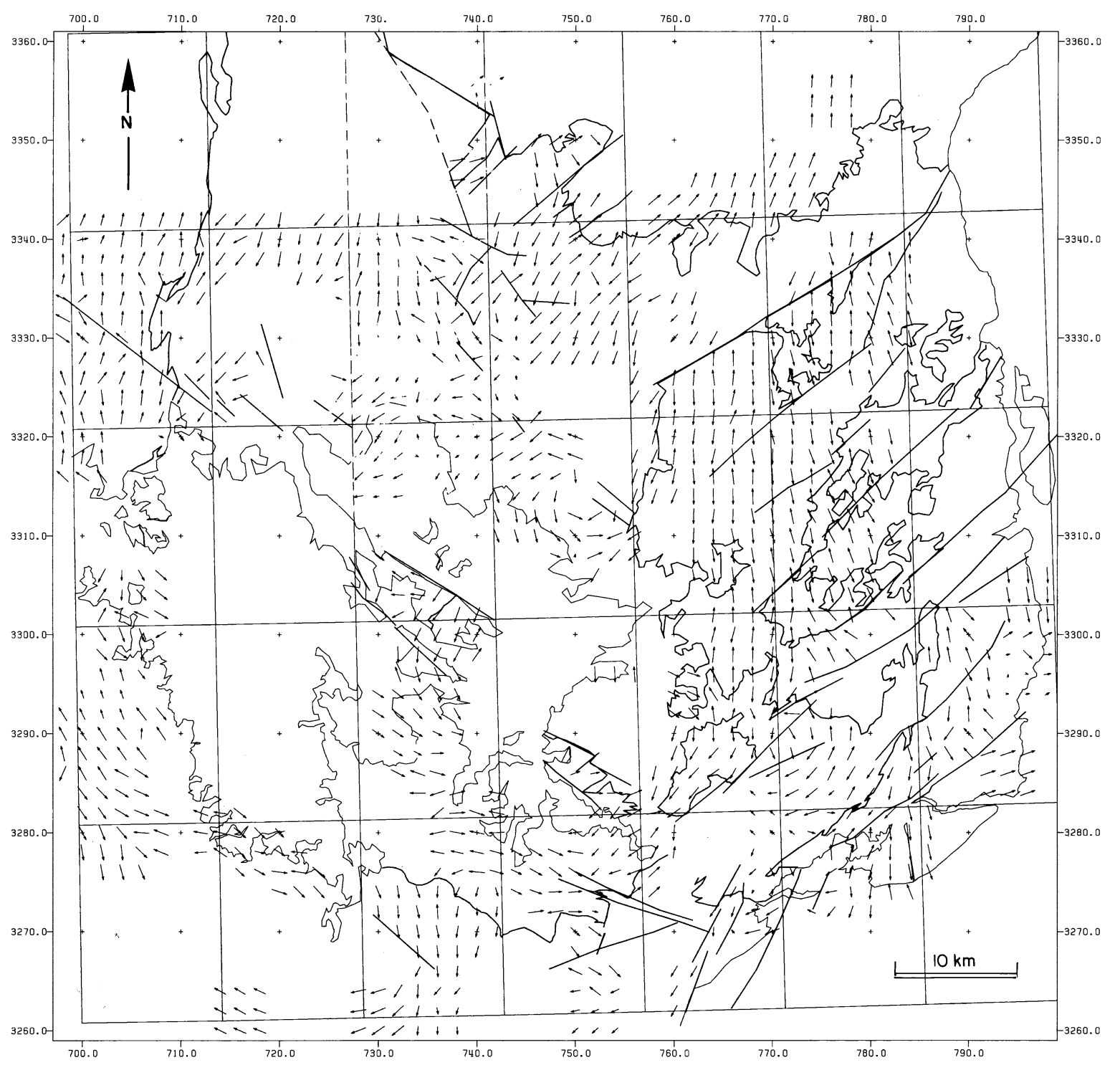

Fig. 3. Map of the stretching lineations. The orientation of the lineations is interpolated at the nodes of a kilometre-scale grid with a range of $2 \times 2 \mathrm{~km}$. It is calculated by eigenvector analysis of the covariance matrix. Length of arrow is proportional to the plunge. 


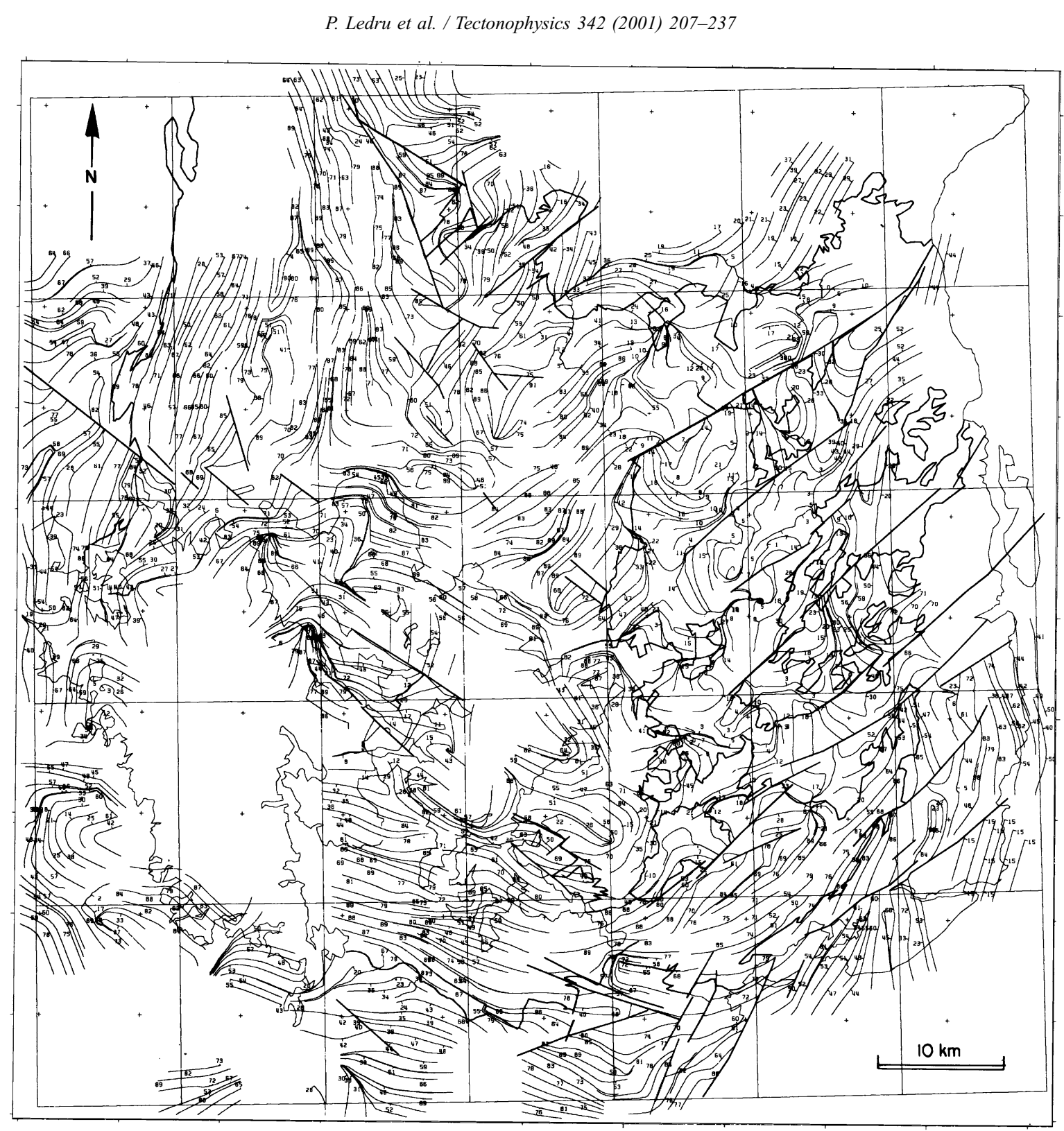

pp. $219-220$

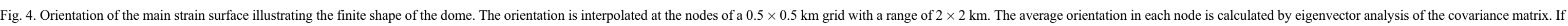
a fault cross-cuts the network, values are treated separately on each side of the fault. Each value is weighted by the reciprocal of the distance to the node of the grid. 
(a)

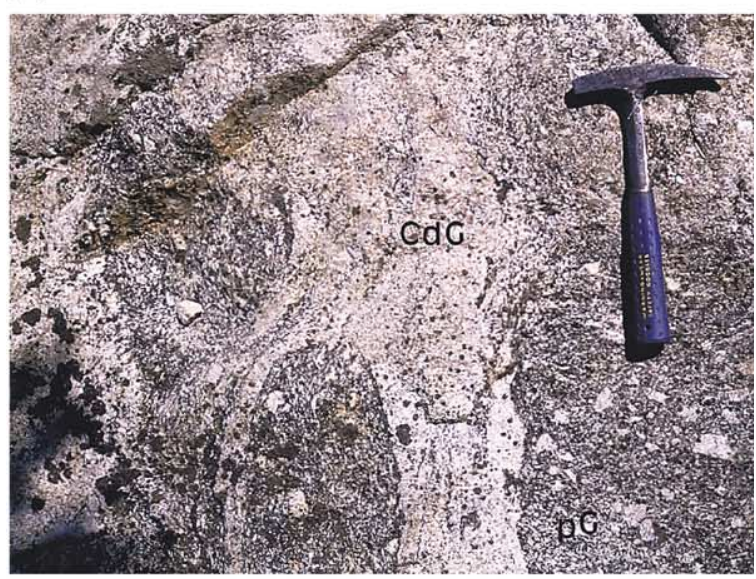

(b)

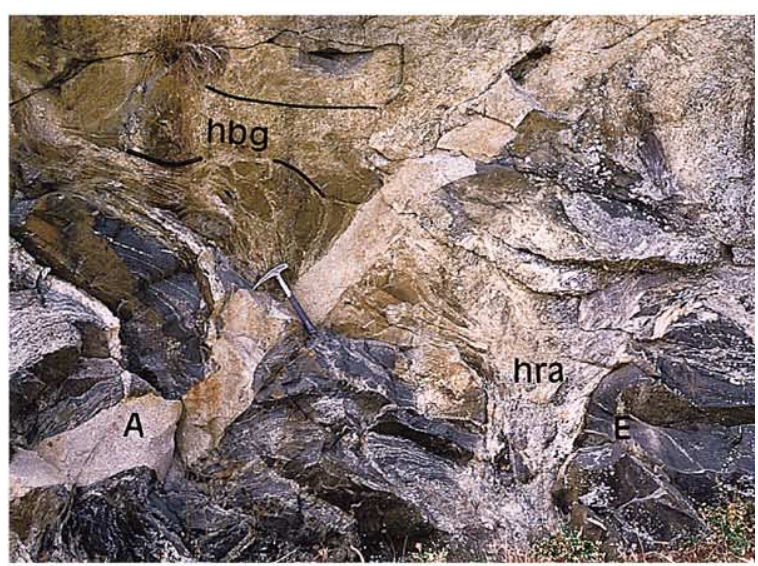

(c)

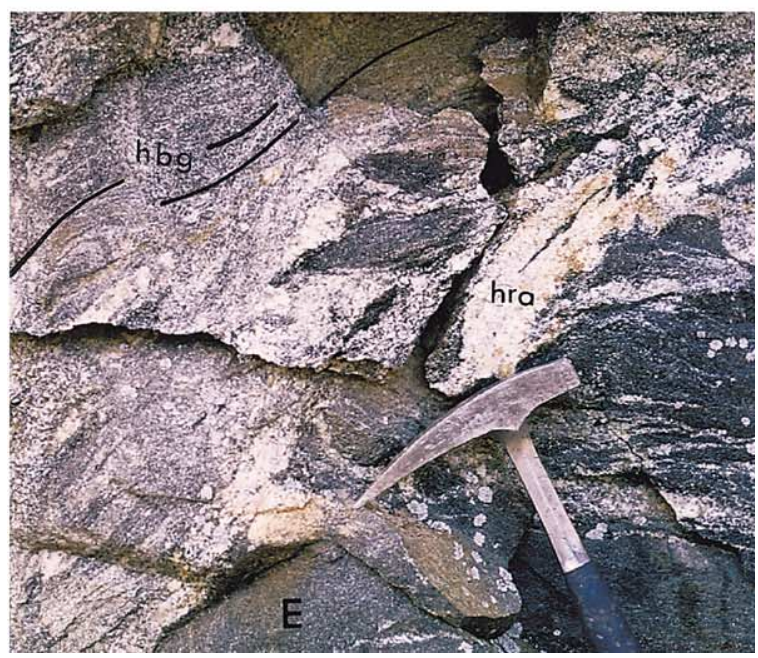

$\mathrm{K}$ magnesian monzodiorite provide evidence for the early involvement of the enriched mantle in this magmatic suite (Pin and Duthou, 1990; Sabatier, 1991).

The characteristics of the main porphyric granites are summarised on Table 2. Geochronologic and geologic arguments suggest that they emplaced between 335 and 315 Ma. The magmatic fabric is weakly developed in the central part of the massifs but well pronounced at their margins. At the base of the laccoliths, metric to decametric sheets are injected parallel to the foliation of the host rocks (Feybesse et al., 1995). Planar and linear fabrics, locally mylonitic textures, are well developed within these granitic sheets, defined by orientation of large $\mathrm{K}$ feldspar phenocryst and biotite. Kinematics criteria define a top to the south sense of shear. Foliation of the host rocks is marked by the preferred orientation of biotite-andalusite or biotite-sillimanite, in continuity with the magmatic fabric, indicating that regional deformation and plutonism were coeval. At the regional scale, foliation trajectories in granites are in continuity with the foliation of their host rocks, both being refolded by the $\mathrm{D}_{4 \mathrm{~b}}$ peripheral folding. Accordingly, these granites appear to be emplaced during the Neovariscan $\mathrm{D}_{3}$ tectonic phase as defined above in the host rocks of the laccoliths (Table 1).

\subsection{The Velay migmatites}

The migmatites that appear in the core of the Velay dome range from metatexites, whose structure was inherited from the parent gneiss, to diatexites and granites. Migmatites preserving $\mathrm{K}$ feldspar phenocrysts and diatexites with biotite - sillimanite \pm cordierite derived, respectively, from ortho and paragneisses of the Lower Gneiss Unit (Plate 1). Large rafts of migmatitic gneisses preserved within the granite dome may be screens between intrusions or refractory layers. Centimeter size micaceous enclaves are com-

Fig. 5. The precursor plutons of the Velay migmatite-granite dome. (a) Porphyric granite intrudes by cordierite-bearing granite (Privas, southern margin of the Velay dome). (b,c; detail) High-K magnesian monzodiorite enclave (vaugnerite) (E) within the heterogeneous banded biotite granite (hbG). Hololeucocratic reaction aureoles (hra) are well developed at the margin of the enclave. An aplite dyke (A) cross-cuts these primary magmatic features (Firminy, northern margin of the Velay dome). 
Table 2

Main characteristics of the precursor plutons of the Velay migmatite-granite dome

\begin{tabular}{|c|c|c|c|}
\hline Region & Name of the pluton & Structural context & Age, method and references \\
\hline Northeast & Civrieux granite & $\begin{array}{l}\text { Syntectonic granite emplaced in the } \\
\text { dextral NE-SW strike-slip faults }\end{array}$ & $\begin{array}{l}339 \pm 8 \mathrm{Ma}(\mathrm{Rb}-\mathrm{Sr} \text {, whole rock; } \\
\text { Gray et al., 1981) plateau ages } \\
\text { between } 350 \text { and } 335 \mathrm{Ma}(\mathrm{Ar} 39-40 \\
\text { on biotites; Costa et al., } 1993)\end{array}$ \\
\hline Northeast & $\begin{array}{l}\text { Gouffre d'Enfer } \\
\text { granite }\end{array}$ & Penetrative extensional deformation & $\begin{array}{l}322 \pm 9 \text { Ma (Caen Vachette et al., } \\
\text { 1984; Vitel, 1988) }\end{array}$ \\
\hline West & $\begin{array}{l}\text { Chaise Dieu } \\
\text { porphyritic granite } \\
\text { and leucogranite }\end{array}$ & $\begin{array}{l}\text { Laccolith }\left(45 \mathrm{~km}^{2}, 2-4-\mathrm{km} \text { thick), }\right. \\
\text { highly strained on its southern } \\
\text { margin, southward displacement } \\
\text { along subhorizontal shear surfaces } \\
\text { and northerly trending sinistral } \\
\text { faults (Feybesse et al., 1995) }\end{array}$ & \\
\hline Southwest & Margeride granite & $\begin{array}{l}\text { Laccolith }\left(3000 \mathrm{~km}^{2}, 5-\mathrm{km} \text { thick}\right) \text {, } \\
\text { presents a mylonitic texture at its } \\
\text { base with south-verging criteria } \\
\text { (Feybesse et al., 1995) }\end{array}$ & $\begin{array}{l}323 \pm 12 \mathrm{Ma}(\mathrm{Rb}-\mathrm{Sr} \text {, whole rock; } \\
\text { Couturié and Caen-Vachette, 1979), } \\
334 \pm 7 \mathrm{Ma}(\mathrm{U}-\mathrm{Pb} \text {; Respaut, 1984), }\end{array}$ \\
\hline Southwest & $\begin{array}{l}\text { Margeride } \\
\text { leucogranites }\end{array}$ & $\begin{array}{l}\text { Small intrusive bodies, post-dating } \\
\text { the deformation of the Margeride } \\
\text { granite }\end{array}$ & $\begin{array}{l}305 \pm 4 \mathrm{Ma}(\mathrm{U}-\mathrm{Pb} \text { monazite; } \\
\text { Lafon and Respaut, 1988) }\end{array}$ \\
\hline South & Rocles granite & Syntectonic laccolith & $\begin{array}{l}302 \pm 4 \mathrm{Ma}(\mathrm{Rb}-\mathrm{Sr} \text {, whole rock; } \\
\text { Caen Vachette et al., 1981) }\end{array}$ \\
\hline South & $\begin{array}{l}\text { Monzodiorite to } \\
\text { monzogabbrodiorite } \\
\text { with shoshonitic } \\
\text { affinities }\end{array}$ & Enclaves and small intrusive bodies & $\begin{array}{l}313 \pm 3 \text { and } 314 \pm 3 \mathrm{Ma} \\
\left({ }^{207} \mathrm{~Pb}-{ }^{206} \mathrm{~Pb} \text { and } \mathrm{U}-\mathrm{Pb},\right. \\
\text { respectively; Ait Malek, 1997) }\end{array}$ \\
\hline Southeast & Tournon granite & $\begin{array}{l}\text { Laccolith }\left(130 \mathrm{~km}^{2}, 2-4-\mathrm{km} \text { thick), }\right. \\
\text { presents a sill complex highly } \\
\text { strained on its southern margin }\end{array}$ & $\begin{array}{l}337 \pm 13 \mathrm{Ma}(\mathrm{Rb}-\mathrm{Sr} \text {, whole rock; } \\
\text { Batias and Duthou, 1979) }\end{array}$ \\
\hline
\end{tabular}

mon as residual unmolten mineral assemblages throughout the dome.

The foliation trajectories at the periphery of the dome are affected by $\mathrm{D}_{4 \mathrm{~b}}$ folding with axial plane parallel to the contact of the dome (Fig. 4, Plate 1). Second order domes as the Alleyras dome were formed by the interference between south-verging $\mathrm{D}_{3}$ and $\mathrm{D}_{4 \mathrm{~b}}$ folds (Feybesse et al., 1995). $\mathrm{D}_{4 \mathrm{~b}}$ folds are overturned to the SE in the southeastern edge of the Velay dome (Lagarde et al., 1994) reflecting the southward expansion of the dome. Synmigmatitic way-up criteria preserved in metatexites suggest that the foliation was tilted from a horizontal position to its current subvertical to overturned dip during doming (Burg and Vanderhaeghe, 1993).

At the roof of the eastern part of the dome, in the region of Annonay, the gneissic units crop out as large wavelength synforms, geometrically related to the host rocks of the Lower Gneiss Unit to the North
(Figs. 4 and 6, Plate 1). From the base to the top, several sections show: a discontinuous layer of migmatitic paragneiss, migmatitic orthogneiss overlain by nonmigmatitic orthogneiss, and micaschist with amphibolite layers (Plate 1). This stack is affected by $\mathrm{N}-$ $\mathrm{S}$ extension, with a shear zone particularly well marked within orthogneiss where foliation is flat lying and stretching lineation $\mathrm{N}-\mathrm{S}$ trending. Microstructural studies and preferred orientation of quartz $\langle C\rangle$ axes show that leucosomes underwent hightemperature plastic deformation in a noncoaxial strain regime, consistent with a top to the north sense of shear (Fig. 7a). Granite intrusions in the vicinity of this fault also underwent high-temperature plastic deformation consistent with top to the north sense of shear (Fig. 7b,c). This shear zone is interpreted as the southern extension of the Pilat extensional shear zone (Malavieille et al., 1990). Further to the South, an orthogneiss located at the roof of the dome dis- 


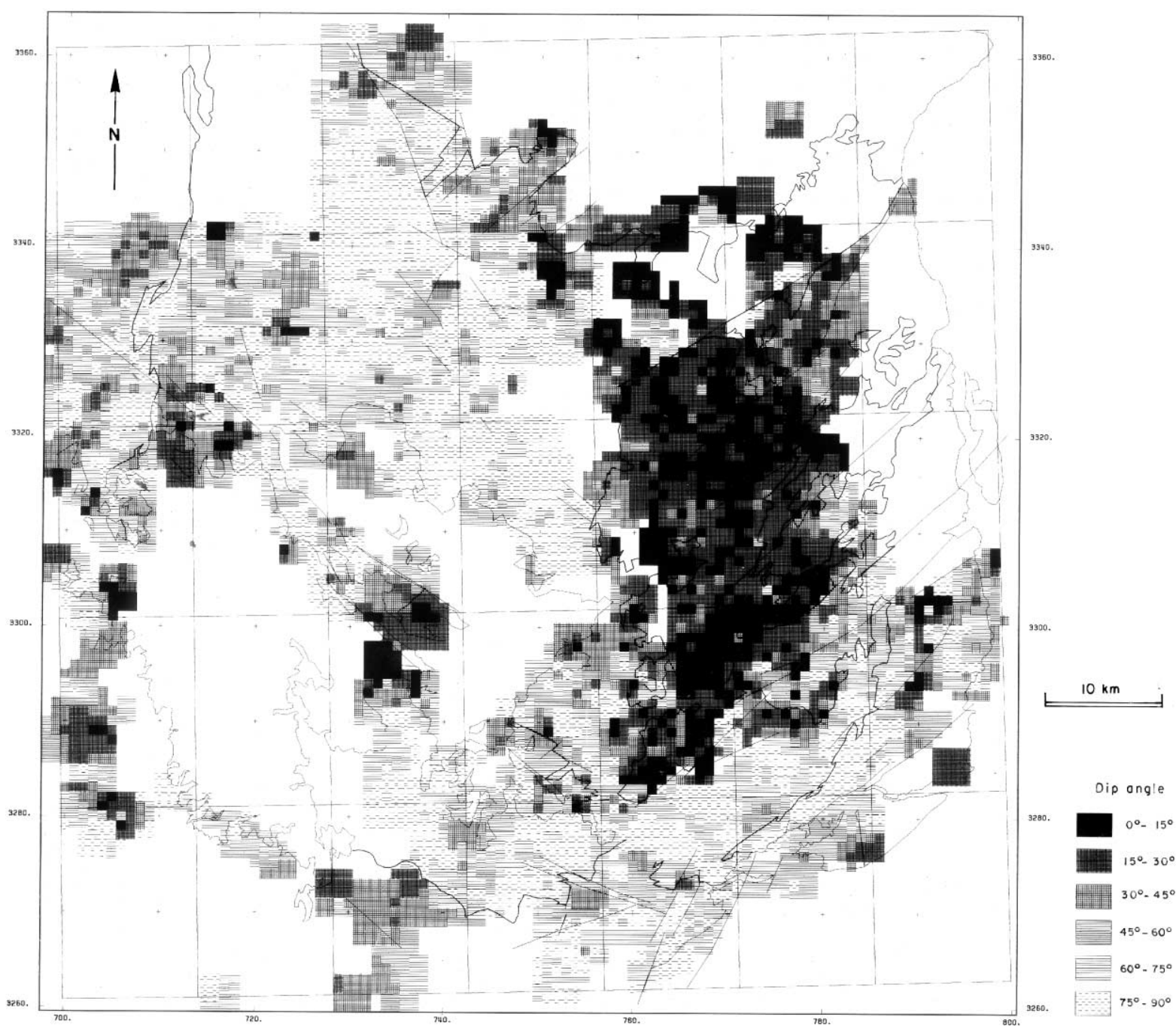

Fig. 6. Map of foliation dip isovalues. Subvertical zones are shown in pale grey and subhorizontal zones are in black. 
plays conjugate extensional shear zones with a $\mathrm{N}-\mathrm{S}$ stretching lineation (Figs. 4, 6 and 3). At the regional scale, these shear zones are folded by antiformal $\mathrm{D}_{4 \mathrm{~b}}$ structures cored by granitic domes. These observations suggest that the granites partly emplaced along crustal-scale normal shear zones and achieved their final ascent while the main activity along this fault system had ceased.

In the migmatites and in the gneissic hosts, the following melting reactions are identified (Fig. 8).

- The first melting stage developed under $P-T$ conditions exceeding those for water-saturated quartzfeldspathic rocks, with biotite remaining stable: around $700{ }^{\circ} \mathrm{C}, 4 \mathrm{kbar}$ within the metamorphic envelope, 5 kbar in the granitic core $\left(\mathrm{M}_{3}\right.$ stage of Montel et al., 1992). The presence of corundum paragneiss enclaves confirms the initial presence of muscovite and the prograde character of this melting event (Ait Malek et al., 1995). A U- $\mathrm{Pb}$ monazite date indicates a minimum age of $314 \pm 5$ Ma (Mougeot et al., 1997). High-K magnesian monzodiorite, with mantellic affinity are also dated at $313 \pm 3$ and $314 \pm 3 \mathrm{Ma}\left({ }^{207} \mathrm{~Pb}-{ }^{206} \mathrm{~Pb}\right.$ and $\mathrm{U}-\mathrm{Pb}$, respectively on zircon, Ait Malek, 1997). They contain peraluminous xenoliths that record a first stage of isothermal decompression at $700-800{ }^{\circ} \mathrm{C}, 8-10 \mathrm{~kb}$, consistent with a source located more than $30-\mathrm{km}$ deep, followed by a stage at $5-6 \mathrm{~kb}$ (Montel, 1985). In view of the water-saturated conditions, it is unlikely that large quantities of granite (i.e. $<10-20 \%$ ) were produced and extracted at this stage (Patiño Douce and Johnston, 1990).

- The second stage of melting is characterized by high-temperature metamorphism in the cordierite stability field, with biotite destabilized: $760-850{ }^{\circ} \mathrm{C}$, 4.4-6.0 kbar (stage $\mathrm{M}_{4}$ of Montel et al., 1992). Leucosomes were dated at $298 \pm 8$ Ma based on $\mathrm{Rb}-\mathrm{Sr}$ whole rock isochron (Caen Vachette et al., 1982), and $\mathrm{Rb}-\mathrm{Sr}$ whole rock-biotite isochrons yield ages between 305 and 276 Ma (Williamson et al., 1992). An age of $301 \pm 5$ Ma was obtained for the homogeneous parts of the granite using the $\mathrm{U}-\mathrm{Pb}$ monazite method (Mougeot et al., 1997). Therefore, this second melting stage is considered to be generally synchronous with emplacement of the main cordierite-bearing granites. The volume of cordierite-bearing granites generated makes a case for massive partial melting at this stage, associated to destabilization of hydrous minerals.
The structural and textural evolution of the migmatites reflects the progressive impact on the rheologic behaviour of the partially molten rocks. The location of early melting is controlled by foliation anisotropy (Fig. 9a,b, Macaudière et al., 1992). In orthogneiss, anatexis first develops with the resorption of quartz along the exiting foliation (Dallain et al., 1999). The breakdown of muscovite is then accompanied by the growth of sillimanite and replacement of quartz-plagioclase aggregates by assemblages that are in equilibrium with the granite eutectic point, although $\mathrm{K}$-feldspar aggregates are preserved. The breakdown of biotite is responsible for the production of melt beyond $30-50 \%$ (Dallain et al., 1999), the value of the Rheological Critical Melt Percentage (Arzi, 1978). Leucosomes with cockade-type cordierite produced during this second melting stage tend to be discordant with the inherited structure (Fig. 9c). Structural orientations then become more varied as the leucosome proportion increases, with folds becoming abundant and randomly oriented (Fig. 9d). This dispersion may reflect complex viscous flow within a dense suspension (Arzi, 1978; Van der Molen and Paterson, 1979; Burg and Vanderhaeghe, 1993).

\subsection{The Velay granites}

The various granites that appear in the Velay dome define a suite, with three main granite types distinguished according to age, structure, homogeneity, mineralogy and geochemistry (Plate 1).

(1) A heterogeneous banded biotite granite, found mainly on the western margin of the dome and locally on the southern and eastern margin (Fig. 5b). It corresponds to the first generated granite of the Velay suite. Foliation trajectories are in continuity with porphyric granites in the external rim of the dome suggesting a continuity between these precursor granites and the development of the heterogeneous banded biotite granite.

(2) A main biotite-cordierite granite, in which several subtypes may be distinguished, in particular according to the cordierite habitus (Barbey et al., 1999).

- A heterogeneous banded granite with abundant enclaves (Fig. 10a). Most of these enclaves represent incorporated and partly assimilated pieces of the 
(a)

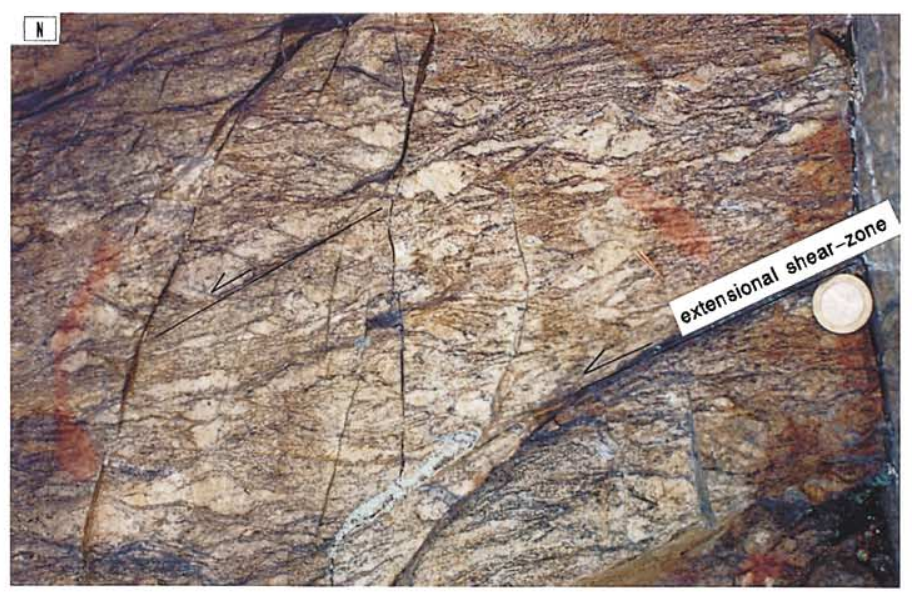

(b)

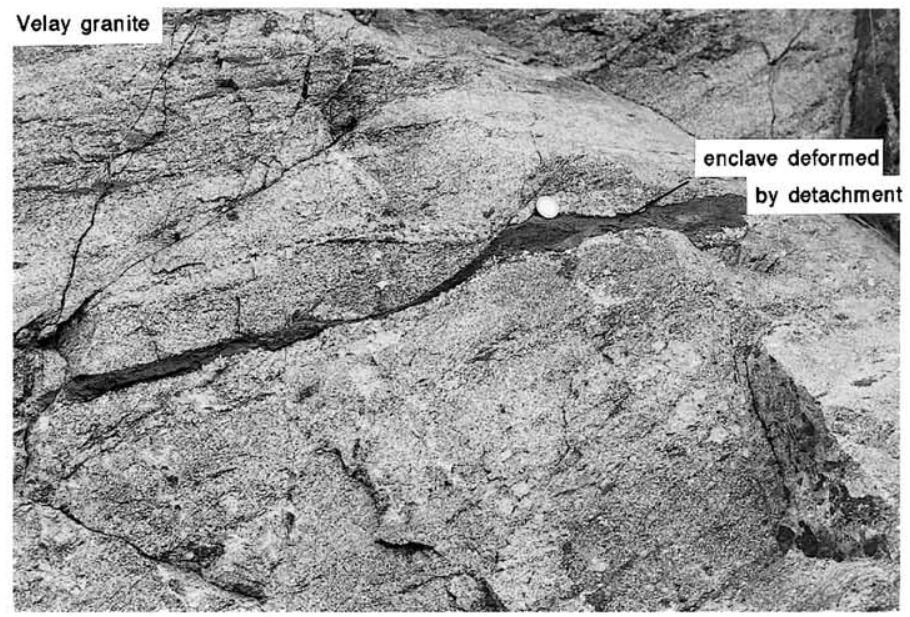

(c)

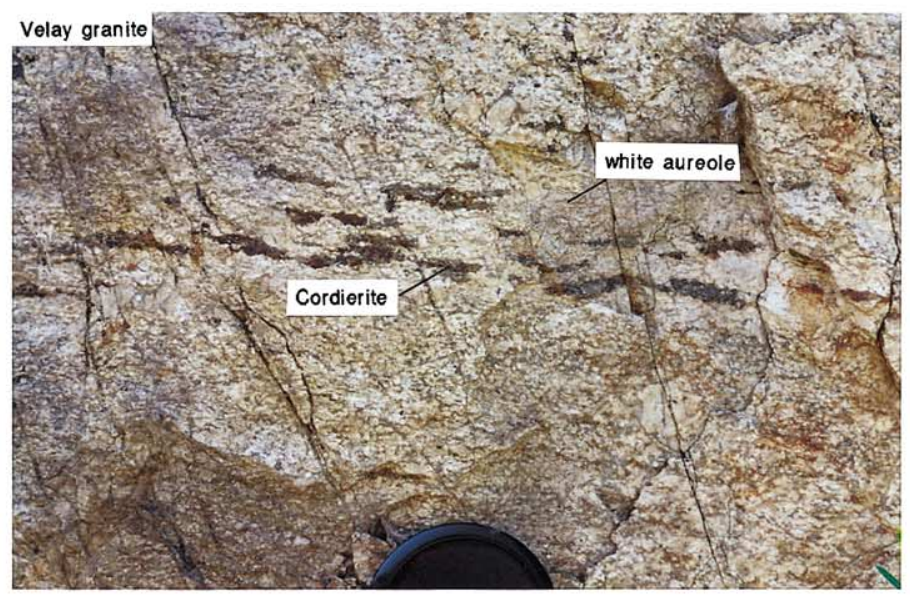




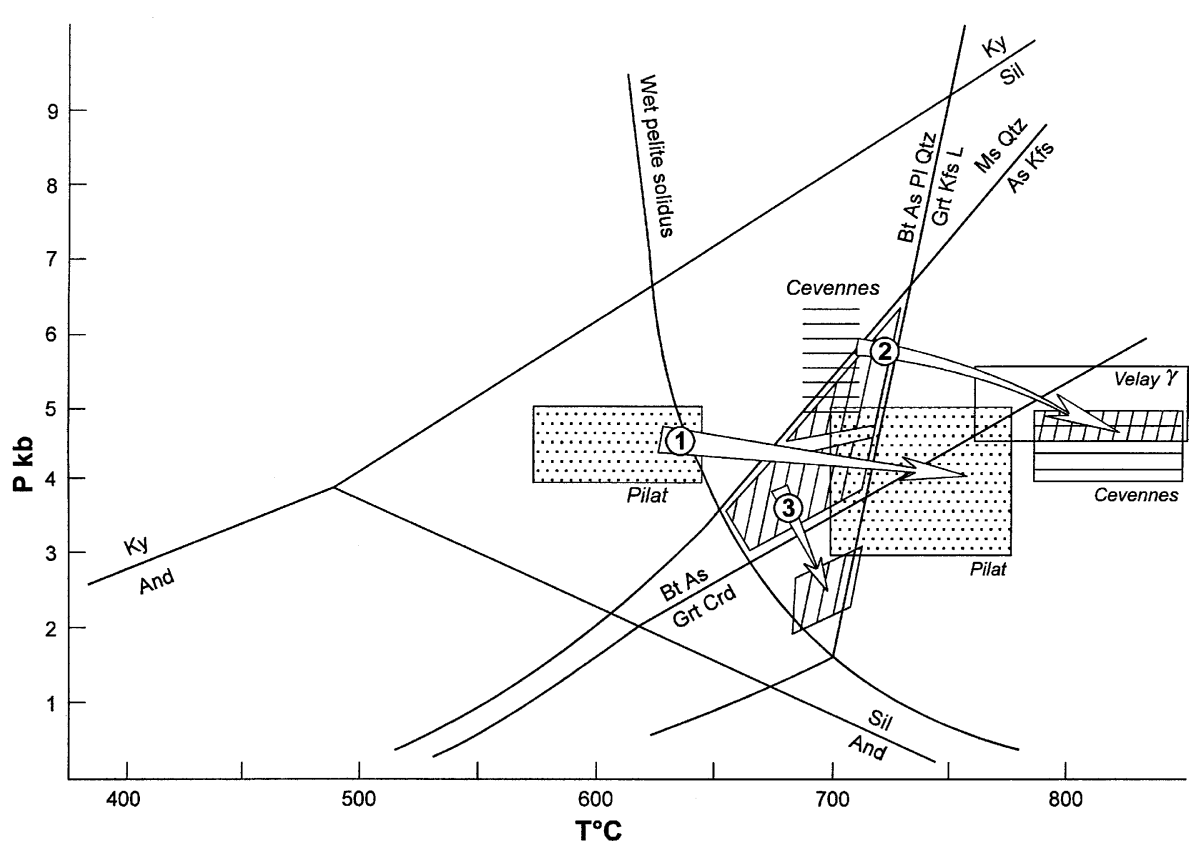

Fig. 8. Pressure-temperature evolution from the gneisses to the Velay granite. Mineral abbreviations: Ky=kyanite; Sil=sillimanite; And = andalusite; $\mathrm{Cd}=$ cordierite; $\mathrm{Grt}=$ garnet; $\mathrm{Ms}=$ muscovite; $\mathrm{Qtz}=$ quartz; $\mathrm{Kfs}=$ potassium feldspar; $\mathrm{Pl}=$ plagioclase; $\mathrm{Bt}=$ biotite; As = aluminium silicate; $L=$ liquid. The transition from the $M_{3}$ to the $M_{4}$ metamorphic stage is indicated by arrows (1) in the Pilat mica schist (after Gardien et al., 1990), (2) in the migmatitic orthogneiss and granite in the southern part of the dome (oblique- and horizontal-ruled boxes, after Gardien et al., 1997; Montel et al., 1992), and (3) in the migmatitic part of the southern host rocks of the Velay granite (obliqueruled boxes, after Montel et al., 1992).

Lower Gneiss unit and precursor plutons originating from the host rocks, although some enclaves with refractory composition or granulite facies metamorphism have a lower crustal origin (Vitel, 1985). Cordierite may be prismatic, cockade-type or mimetic overprinting previous biotite-sillimanite assemblages. Most of the heterogeneous granites indicate mixing between melts of lower-crustal origin and melts from the para- and ortho-derived host rock (Williamson et al., 1992).

- A homogeneous leucocratic biotite-cordierite granite with mainly cockade-type cordierite (Fig. 10b). Its emplacement has been dated at $301 \pm 5 \mathrm{Ma}$ using the $\mathrm{U}-\mathrm{Pb}$ method on monazite (Mougeot et al., 1997).

- A homogeneous granite with biotite and prismatic cordierite as a primary ferromagnesian phase, with few enclaves. The heterogeneous and homogeneous granites with prismatic cordierite, with a high $\mathrm{Sr}$ content, have a mixed isotopic signature between the host rocks and a lower-crustal origin. The deep source is considered to be the melting of the lower mafic/felsic plutonic crust (Williamson et al., 1992).

A leucocratic granite with cockade-type cordierite, without enclaves (Fig. 10c). The cordierite-quartz aggregates posdate primary biotite bearing assemblages and probably prismatic cordierite.

(3) The late magmatic activity that includes:

- Homogeneous granite with K-feldspar porphyrocrysts and common prismatic cordierite, basic and micaceous inclusions (the Quatre Vios massif) (Fig. 10d). These granites are defined as late-migmatitic and are considered to be originated from melting of

Fig. 7. Extensional ductile shear zones. (a) Within an orthogneiss which constitutes a decakilometre-scale enclave (south of Malleval shear zone, northern margin of the Velay Massif). (b,c; detail) Within the Velay granite (Malleval shear zone, northern margin of the Velay Massif). 
(a)

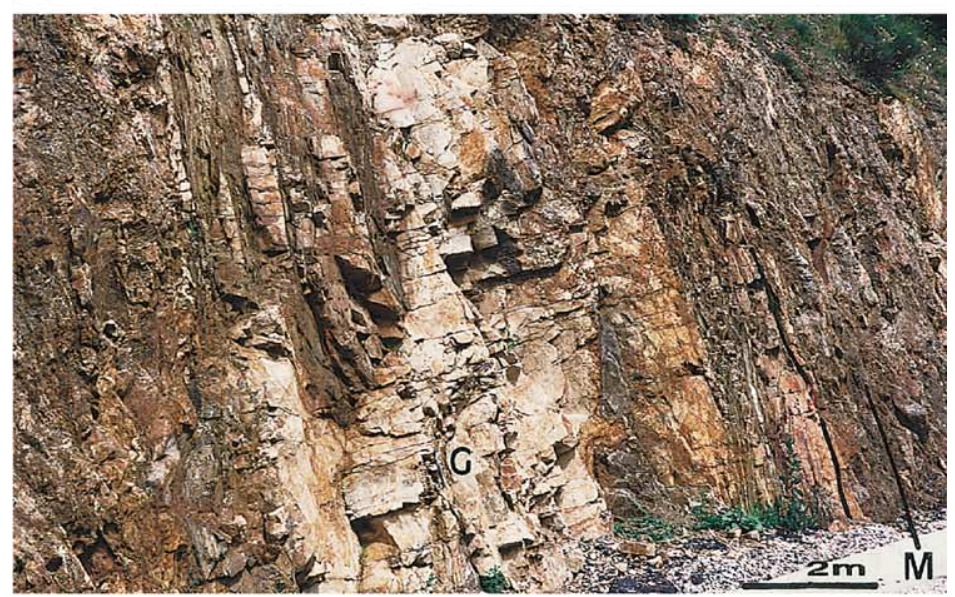

(b)

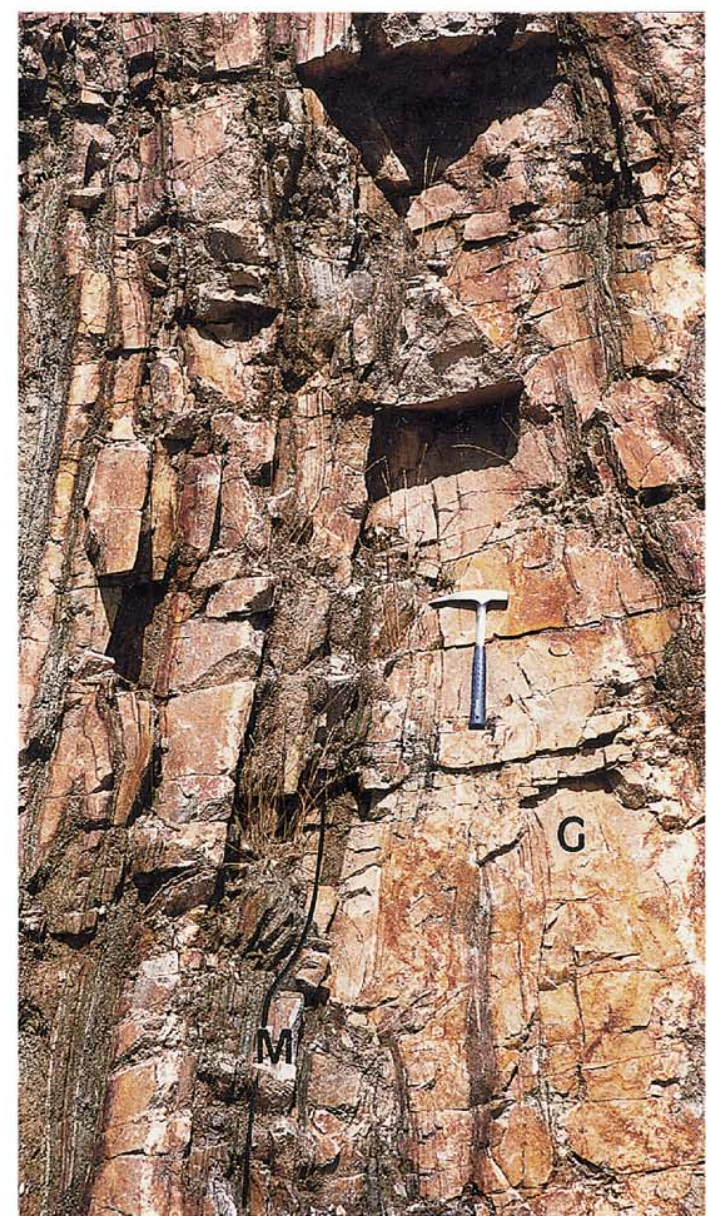


(c)

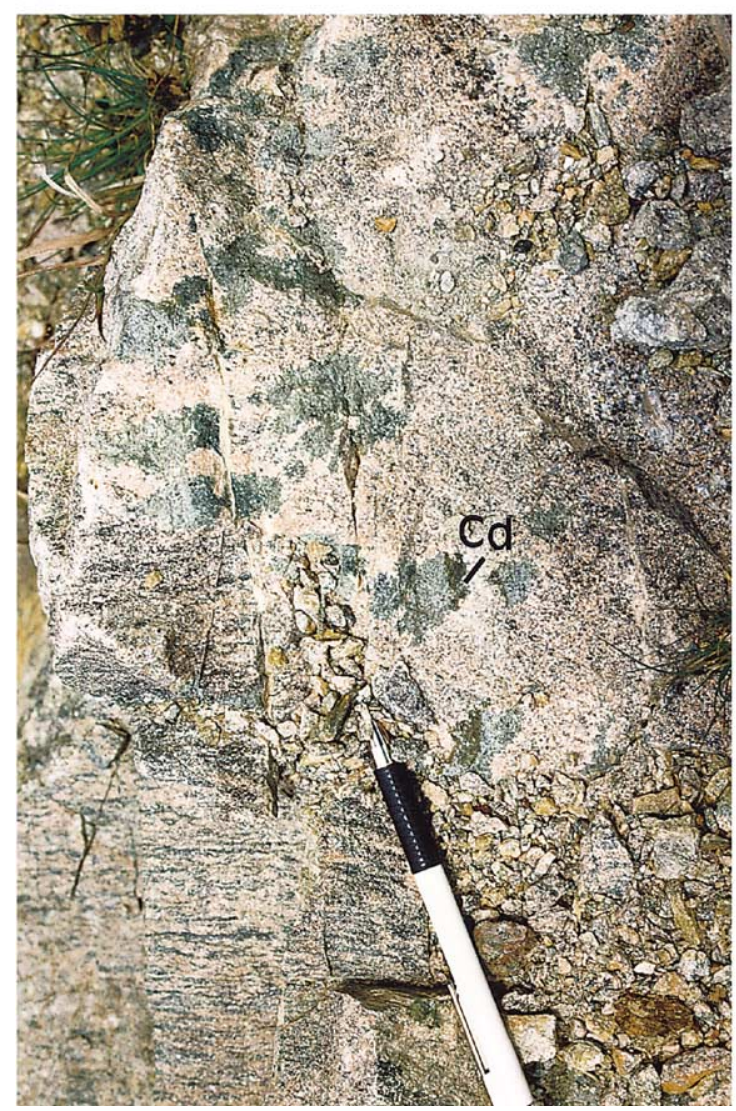

(d)

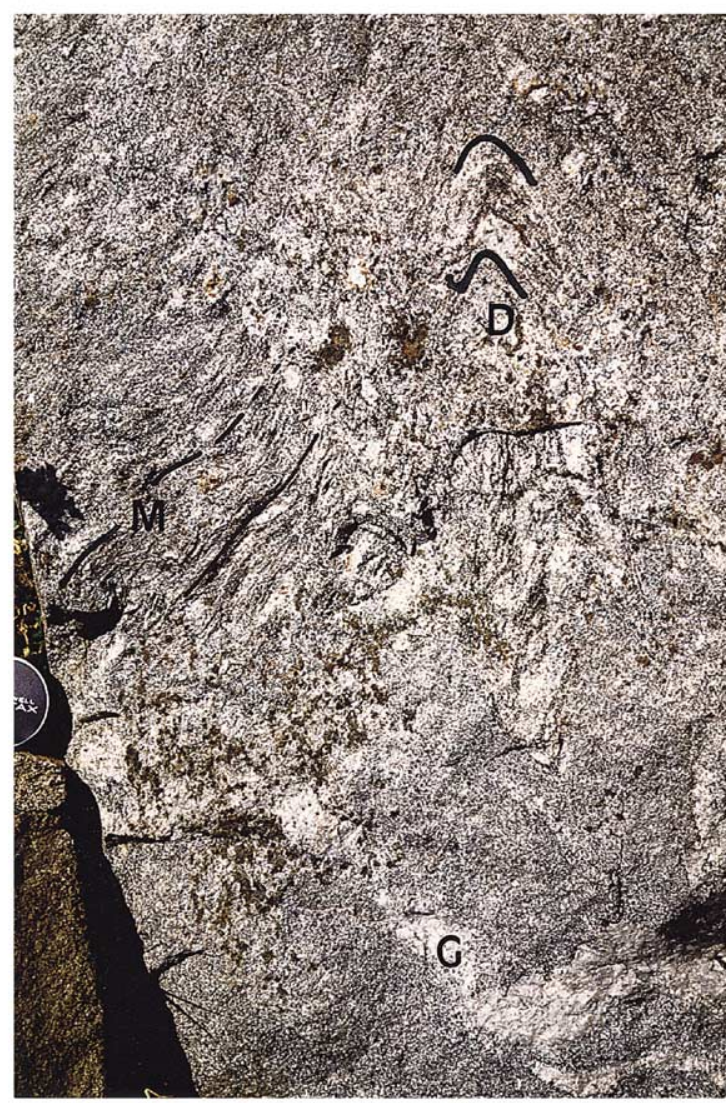

Fig. 9. Melting processes and related structures. (a,b; detail) Metatexites (M) and granitic intrusion (G). Migmatization developed within a paragneiss, which constitutes a hectometre-scale enclave in the core of the Velay Massif (south of Monistrol-sur-Loire). Granite veins are discordant or concordant to the foliation of the paragneiss. (c) Cockade-type cordierite (Cd) melts associated with the $\mathrm{M}_{4}$ stage (Privas, southern margin of the Velay dome). (d) Transition from metatexite (M) to diatexite (D) and granite (G) (Privas, southern margin of the Velay dome).

aluminous sediments at $4.5-5.5 \mathrm{kbar}$ and $750-850$ ${ }^{\circ} \mathrm{C}$, under water-undersaturated conditions and have a significant basic component (Montel et al., 1986; Montel and Abdelghaffar, 1993). Ages at $274 \pm 7$ $\mathrm{Ma}(\mathrm{Rb} / \mathrm{Sr}$ whole rock, Caen Vachette et al., 1984) are considered to be partially reset during Permian or Mesozoic hydrothermal event (Montel et al., in press).

- Stephanian leucogranites, microgranite and aplite-pegmatite dykes, Permian rhyolites. Microgranite dykes have been dated at $306 \pm 12$ and $291 \pm 7$ Ma (microprobe dating of monazite, Montel et al., in press).
The composite and heterogeneous nature of the Velay dome reflects the successive generation and emplacement history of this granitic suite. In contrast, the fabric found in migmatites and granites seems relatively simple at the scale of the dome. Except within the leucocratic granite, foliation is well defined by mineral and enclave orientation, developed during magma crystallization and final formation of the dome, delineating the shape of the dome (Fig. 4). Granites are found in the core of second order antiformal structures (Plate 1). Foliation dip isovalues reveal the contrast between the steep western half and the flat eastern half (Fig. 6). The stretching lineation 
marked by mineral alignment or enclaves elongation is radial at the scale of the dome, well marked on the southern margin, changing from NE-SW to SE-NW. The vertical plunge of the lineation in the central part of the dome is interpreted as related to the vertical flow of the magma from its source (Fig. 3, Lagarde et al., 1994).

A $\mathrm{N}-\mathrm{S}$ cross-section shows that foliations are overturned on the southeastern margin of the dome dipping toward the inner part of the dome (Plate 1). These variations within the granite and migmatite are interpreted as being associated with the southward expansion of the Velay granite during emplacement (Lagarde et al., 1994).

Late-migmatitic granites are oriented NE-SW in the eastern part and NW-SE in the western part of the dome (Plate 1). Detailed mapping of the southern edge of the Velay dome shows that these bodies (a)

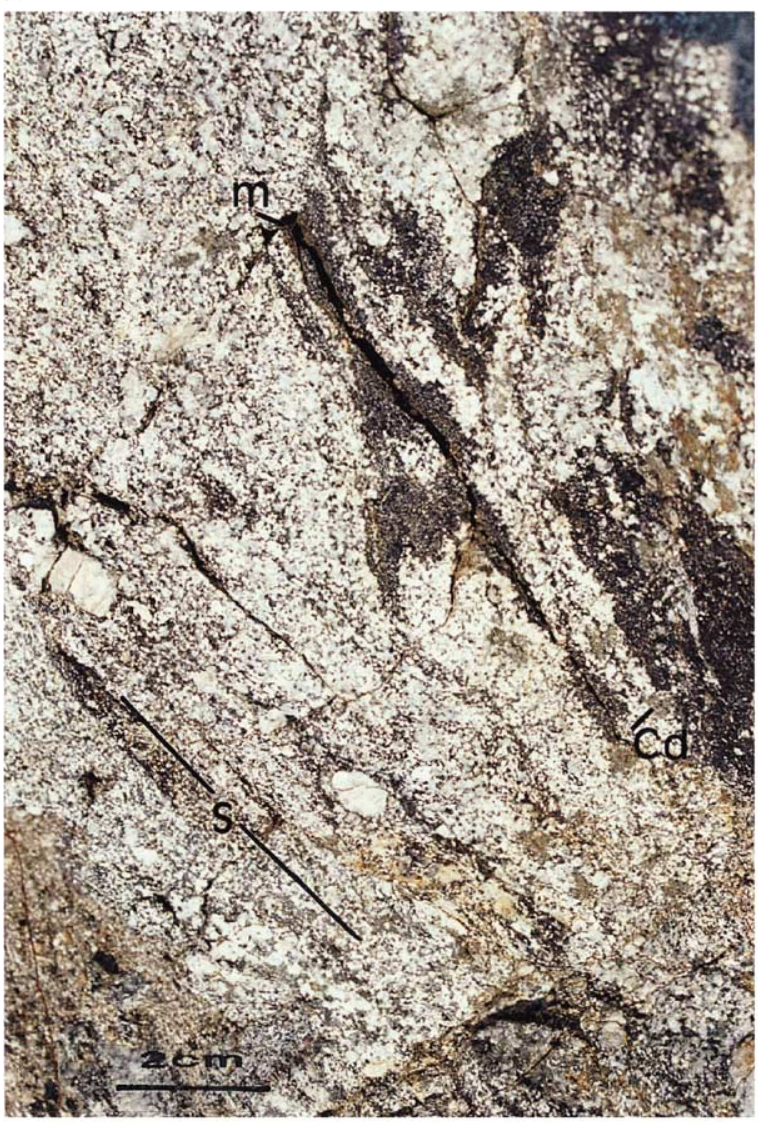

(b)

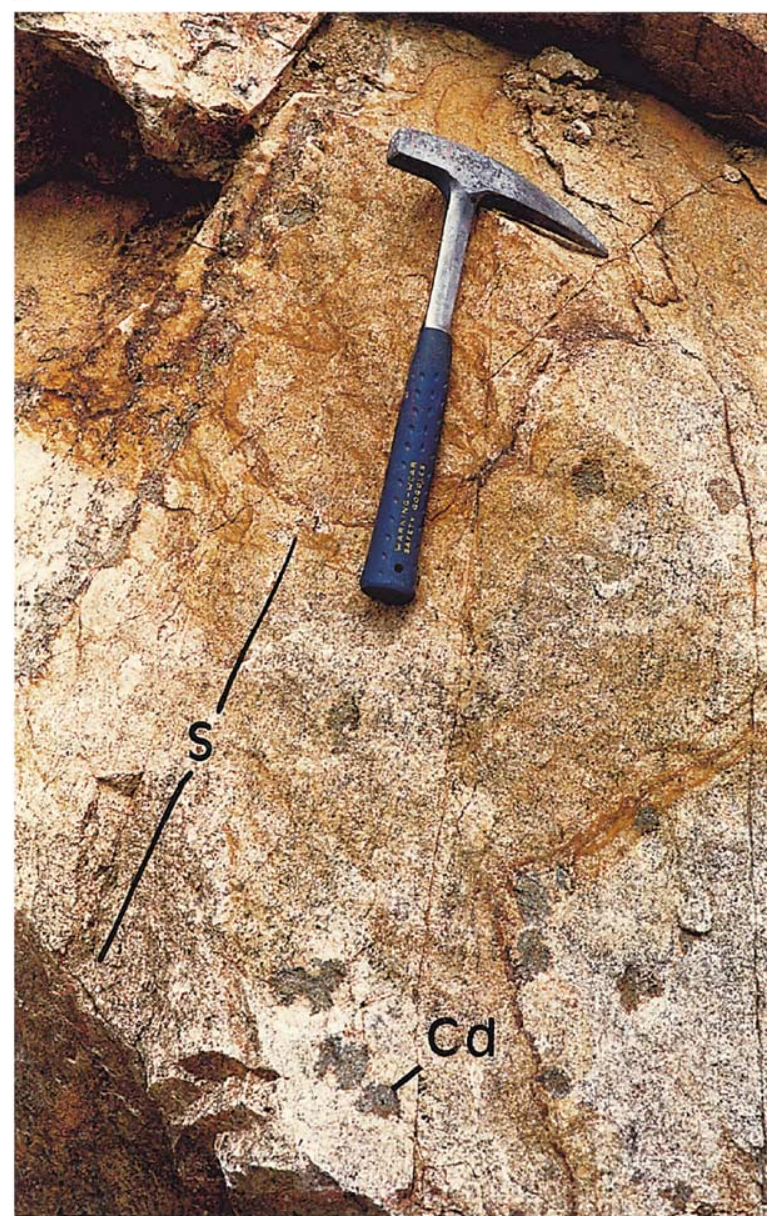

Fig. 10. The main granite types of the Velay migmatite-granite dome (Privas, southern margin of the Velay dome). (a) Heterogeneous banded granite with abundant enclaves. The foliation $(S)$ is marked by the preferred orientation of the biotite and the stretching of the micaceous enclaves (m). Cordierite (Cd) develops as patches in the melt and over the micaceous enclave. (b) Homogeneous leucocratic biotite-cordierite granite with mainly cockade-type cordierite $(\mathrm{Cd})$. The foliation $(\mathrm{S})$ is marked by the preferred orientation of the biotite. (c) Leucocratic granite with cockade-type cordierite (Cd). (d) Late-migmatitic homogeneous granite with basic (b) and micaceous (m) enclaves (the Quatre Vios massif). 
(c)

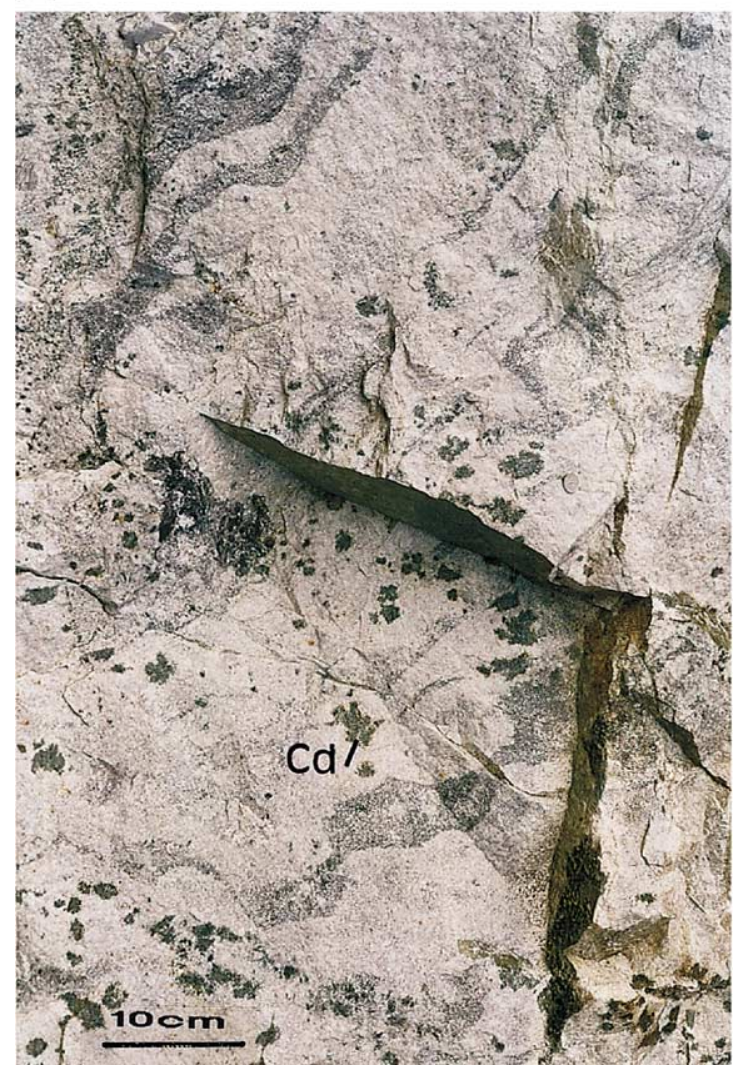

(d)

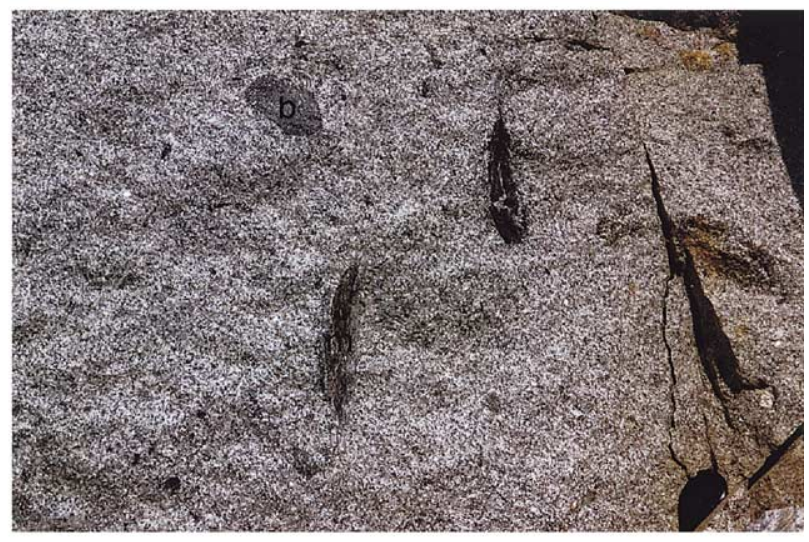

Fig. 10 (continued).

were emplaced as laccoliths rooted in dyke networks.

\section{Discussion: the significance of crustal anatexis in the Velay dome}

The data summarized above allow a reconstruction of the tectonic context and thermal conditions prevailing during the formation of the Velay dome. The first melting event (Fig. 11a), from 340 to at most 314 $\mathrm{Ma}$, developed at temperatures above the water-saturated quartz-feldspar solidus and was coeval with crustal thickening characterized by (a) thrusting of the Upper Gneiss Unit at the roof and margin of the dome, (b) decoupling and stacking of the Lower Gneiss Unit preserved within the migmatites, and (c) metamorphic paragenese of the Cévennes micas- chists (Arnaud, 1997). At this stage, thermal relaxation and heat production within the thickened crust were probably the main causes of temperature increase (England and Thompson, 1984; Huerta et al., 1998). The emplacement of the peri-Velay precursor granites and high-K magnesian monzodiorite magmatism of mantle origin constitute an additional heat source.

Epimetamorphic units from the external zone of the Variscan Belt were progressively involved in the collision, resulting in the burial of fertile pelites and grauwackes that may have contributed to melting because they are a potential source for fluids and rich in hydrous minerals. This melting phase was characterized by the formation of biotite-sillimanite migmatites within which melt extraction was limited to probably less than $20 \%$. The development of migmates within augen orthogneiss at this stage indicates 


\section{$340-314 \mathrm{Ma}$}

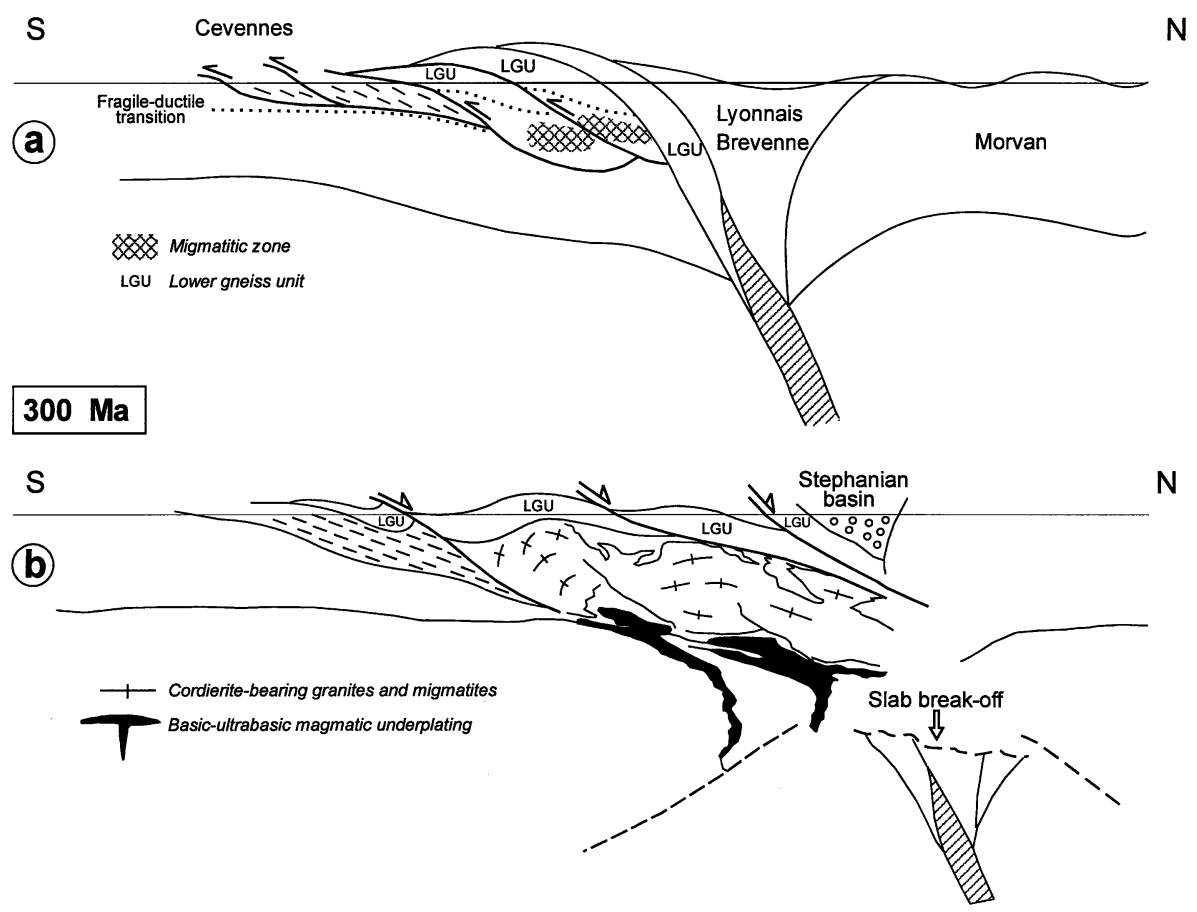

Fig. 11. Schematic tectonic evolution of the eastern edge of the French Massif Central during Carboniferous.

a low melt fraction in the plagioclase-rich rocks, with most of the gneissic structure generated in subsolidus conditions (Dallain et al., 1999).

Once all the free water available had been fractionated in the melt, further melting proceeded by destabilization of biotite responsible for the generation of cordierite-bearing granites (Fig. 11b). According to Barbey et al. (1999), prismatic cordierite both in granites and leucosomes developed as a primary ferromagnesian phase at shallow crustal level while the formation of cockade-type cordierite reflect decompression linked to the ascent of the Velay dome. From a structural point of view, this second melting event is characterized by a generalized extensional tectonics well recorded at the roof of the dome and along northdipping normal detachment zone active between 320 and $300 \mathrm{Ma}$ as the Pilat fault (Malavieille et al., 1990). The activation of these detachments is associated to deposition of Stephanian sediments in between tilted blocks. This combination led to exhumation of the migmatite and granites (Vanderhaeghe et al., 1999).
Leucosomes dated at the southern edge of the dome provide data on the exhumation of the dome as in all samples that were analysed $\mathrm{U}-\mathrm{Pb}$ apatite dates converge at around $290 \mathrm{Ma}$ (Mougeot et al., 1997).

What caused the temperature increase required to melt the Variscan crust from the initial to the final stages? According to current petrological and thermal numerical models (Thompson and Connolly, 1995; Huerta et al., 1998), a simple crustal thickening event followed by erosion can hardly account for the generation of large volumes of granite. Results from experimental petrology show that high melt fractions require conditions well above $800^{\circ} \mathrm{C}$, above the destabilization curves of hydrous minerals (Clemens and Vielzeuf, 1987; Patiño Douce and Johnston, 1990; Gardien et al., 1995). In the Velay dome, partial melting of the thickened crust was intensified when biotite dehydration melting conditions were achieved, which coincided with the initiation of crustal extension. Granulitefacies metamorphism at the base of the Variscan crust is also dated at about $300 \mathrm{Ma}$ (Pin and Vielzeuf, 1983; 
Costa and Rey, 1995). The existence of mantle-derived and granulitic components in the lower crust is indicated by the aluminous and basic enclaves brought up in recent volcanoes (Leyreloup, 1973; Downes et al., 1990). At the scale of the MassifCentral, the $\varepsilon N d$ values of monzogranitic-granodioritic rocks increased with decreasing age from 360 to $300 \mathrm{Ma}$, suggesting either an increasing contribution of a mantle component or the progressive melt of more mafic and refractory crustal sources or both (Pin and Duthou, 1990). According to these authors, the propagation of a large thermal anomaly toward the higher levels of crust was responsible for the large-scale geochemical variations.

Accordingly, we propose a model whereby the extra heat causing voluminous partial melting of the Variscan crust was supplied by asthenospheric upwelling and associated intrusion of mantle-derived magmas at the base of the crust. This asthenospheric upwelling may have been associated with the slab break off (Fig. 11b) and/or thermal erosion of the lithospheric root of the Variscan Belt (e.g. Rey et al., 1997).

\section{Conclusion}

Structural, petrologic and geochronological data presented in this study indicate that the formation of the Velay migmatite-granite dome results from the conjunction of several phenomena.

- Partial melting of the thickened crust started at about $340 \mathrm{Ma}$, while thrusting in the hinterland of the Variscan belt was still active, and ended during collapse of the orogenic crust at $\sim 300 \mathrm{Ma}$. Crustal anatexis responsible for the generation of the rocks forming the Velay dome hence lasted about $40 \mathrm{Ma}$.

- Partial melting took place within a dominantly metasedimentary crustal layer dominated by fertile pelitic compositions. Melting reactions evolved from the water-saturated granitic solidus to destabilization of hydrous minerals and indicate that melting started at the end of the prograde metamorphic path and ended during decompression associated with exhumation of the migmatite-granite dome.

- Thermal relaxation and increased radioactive heat production following crustal thickening likely caused a rise in temperature during the evolution of the Variscan orogenic crust. However, it is proposed that heat advection from mantle-derived magmas and also asthenospheric upwelling coeval with orogenic collapse have provided the extra heat source required to melt a large volume of the thickened crust and generate the migmatites and granites of the Velay dome.

- The formation of the Velay dome, coeval with the activation of crustal-scale detachments, potentially corresponds to flow of a partially molten crustal layer in response to gravitational collapse.

\section{Acknowledgements}

This work has been done in the framework of the research program of the BRGM, financed by the National 50000 Mapping program and finally by GeoFrance 3D. This is GeoFrance 3D publication no. 105. P. Barbey, B. Briand, R. Capdevila, J. Didier, J.L. Feybesse, V. Johan, J.L. Lagarde, J. Macaudière, C. Marignac, K. Schulmann are greatly acknowledged for their involvement in the project at its beginning and for their contribution to some of the themes developed in this article. This synthesis could never have been done without their participation. J. Tabler is thanked for the English translation and C. Heinry for the drawings. Reviews by M. Brown, J. Van den Driessche, C. Tey- ssier and J.P. Burg were greatly appreciated and led to substantial improvement of the original manuscript.

\section{References}

Ait Malek, H., 1997. Pétrologie, Géochimie et géochronologie U/Pb d'associations acide-basiques: exemples du SE du Velay (Massif central français) et de l'anti-Atlas occidental (Maroc). Thèse doctorat de l'INPL, Univ. Nancy, 297 pp. (unpublished).

Ait Malek, H., Gasquet, D., Marignac, C., Bertrand, J.M., 1995. Des xénolites à corindon dans une vaugnérite de l'Ardèche (Massif central français): implications pour le métamorphisme ardéchois. C. R. Acad. Sci. Paris 321, 959-966.

Arnaud, F., 1997. Analyse structurale et thermo-barométrique d'un système de chevauchements varisque: les Cévennes centrales (Massif Central français). Microstructures et mécanismes de déformation dans les zones de cisaillement schisteuses. Thèse 3ème cycle, Institut National Polytechnique de Lorraine, Documents du BRGM, 286, $351 \mathrm{pp.}$

Arnaud, F., Burg, J.P., 1993. Microstructures des mylonites schisteuses: cartographie des chevauchements varisques dans les Cévennes et détermination de leur cinématique. C. R. Acad. Sci. Paris 317, 1441-1447. 
Arzi, A.A., 1978. Critical phenomena in the rheology of partially melted rocks. Tectonophysics 44, 173-184.

Barbey, P., Marignac, C., Montel, J.M., Macaudière, J., Gasquet, D., Jabbori, J., 1999. Cordierite growth texture and the conditions of genesis and emplacement of crustal granitic magmas: the Velay granite complex (Massif Central, France). J. Petrol. 40, 14251441.

Batias, P., Duthou, J.L., 1979. Age Viséen supérieur du granite porphyroïde de Vienne-Tournon (Massif Central français). 7ème R.A.S.T., Lyon, p. 34.

Brown, M., 1994. The generation, segregation, ascent and emplacement of granite magma: the migmatite-to-crustally-derived granite connection in thickened orogens. Earth Sci. Rev. 36, 83-130.

Brown, M., Dallmeyer, R.D., 1996. Rapid Variscan exhumation and the role of magma in core complex formation: southern Brittany metamorphic belt. J. Metamorph. Geol. 14, 361-379.

Burg, J.P., Matte, P., 1978. A cross section through the French Massif central and the scope of its variscan geodynamic evolution. Z. Dtsch. Geol. Ges., Stuttgart 109, 429-460.

Burg, J.P., Vanderhaeghe, O., 1993. Structures and way-up criteria in migmatites, with application to the Velay dome (French Massif central). J. Struct. Geol. 15, 1293-1301.

Burg, J.P., Van Den Driessche, J., Brun, J.P., 1994. Syn- to postthickening extension: mode and consequences. C. R. Acad. Sci. Paris 319, 1019-1032.

Caen Vachette, M., Couturié, J.P., Fernandez, A., 1981. Age westphalien du granite de Rocles (Cévennes, Massif Central français). C. R. Acad. Sci. Paris 293, 957-960.

Caen Vachette, M., Couturié, J.P., Didier, J., 1982. Age radiométrique des granites anatectiques et tardimigmatitique du Velay (Massif Central français). C. R. Acad. Sci. Paris 294, 135-138.

Caen Vachette, M., Gay, M., Peterlongo, J.M., Pitiot, P., Vitel, G., 1984. Age radiométrique du granite syntectonique du gouffre d' Enfer et du métamorphisme hercynien dans la série de basse pression du Pilat (Massif Central Français). C. R. Acad. Sci. Paris 299, 1201-1204.

Caron, C., Lancelot, J.R., Maluski, H., 1991. A paired 40Ar-39Ar and $\mathrm{U}-\mathrm{Pb}$ radiometric analysis applied to the variscan Cévennes, French Massif central. EUG Strasbourg, Terra Abstr. 3, 205.

Chantraine, J., Autran, A., Cavelier, C., 1996. Carte Géologique De La France à $1 / 1000000,6$ th edn. Publ. BRGM.

Chenevoy, M., Ravier, J., 1968. Extension des séries cristallophyliennes à andalousite-cordiérite et à disthène-staurotide dans les Cévennes septentrionales et médianes. Bull. Soc. Geol. Fr. 7, 613-617.

Clemens, J.D., 1990. The granulite-granite connection. In: Vielzeuf, D., Vidal, Ph. (Eds.), Granulites and Crustal Evolution. Kluwer Academic Publishing, pp. 25-36.

Clemens, J.D., Vielzeuf, D., 1987. Constraints on melting and magma production in the crust. Earth Planet. Sci. Lett. 86, 287-306.

Costa, S., Rey, P., 1995. Lower crustal rejuvenation and growth during post-thickening collapse: insights from a crustal cross section through a Variscan core complex. Geology 23, 905-908.

Costa, S., Maluski, H., Lardeaux, J.M., 1993. 40Ar-39Ar chronology of Variscan tectono-metamorphic events in an exhumed crustal nappe: the Monts du Lyonnais complex (Massif Central, France). Chem. Geol. 105, 339-359.
Couturié, J.P., Caen-Vachette, M., 1979. Age Namurien d'un laccolite granitique différencié par gravité: le granite de la Margeride (Massif Central français). C. R. Acad. Sci. Paris 289, 449-452.

Dallain, C., Schulmann, K., Ledru, P., 1999. Textural evolution in the transition from subsolidus annealing to melting process, Velay dome, French Massif Central. J. Metamorph. Geol. 17, 61-74.

Didier, J., 1973. Granites and their enclaves. The bearing of enclaves on the origin of granites, vol. 2. Developments in Petrology Series, vol. 3. Elsevier, Amsterdam, pp. 37-56.

Downes, H., Dupuy, C., Leyreloup, A.F., 1990. Crustal evolution of the Hercynian belt of Western Europe: evidence from lower crustal xenoliths (French Massif Central). Chem. Geol. 83, 209-231.

Dupraz, J., Didier, J., 1988. Le complexe anatectique du Velay (Massif Central français): structure d'ensemble et évolution géologique. Geol. Fr. 4, 73-87.

Dupuy, C., Leyreloup, A.F., Vernieres, J., 1977. The lower continental crust of the Massif central (Bournac, France) - with special reference to REE, $\mathrm{U}$ and Th composition, evolution, heat flow production. Phys. Chem. Earth 11, 401-416.

Duthou, J.L., Chenevoy, M., Gay, M., 1994. Age Rb-Sr, Dévonien moyen des migmatites à cordiérite du Lyonnais (Massif central français). C. R. Acad. Sci. Paris 319, 791-796.

England, P.C., Thompson, A.B., 1984. Pressure Temperature time paths of regional metamorphism: I. Heat transfer during the evolution of regions of thickened continental crust. J. Petrol. $25,894-928$.

Feybesse, J.L., Couturié, J.P., Ledru, P., Johan, V., 1995. Les granites de la Margeride, de Chambon le Château et de St Cristophe: des laccolites synchrones des derniers stades de l'épaississement varisque. Geol. Fr. 1, 27-45.

Gardien, V., 1990. Reliques de grenat et de staurotide dans la série métamorphique de basse pression du Mont Pilat (Massif Central français): témoins d'une évolution tectonométamorphique polyphasée. C. R. Acad. Sci. Paris 310, 233-240.

Gardien, V., Lardeaux, J.M., 1991. Découvertes d'éclogites dans la synforme de Maclas: extension de l'Unité Supérieure des Gneiss à l'Est du massif central. C. R. Acad. Sci. Paris 312, 61-68.

Gardien, V., Thompson, A.B., Grujic, D., Ulmer, P., 1995. Experimental melting of biotite + plagioclase + quartz \pm muscovite assemblages and implications for crustal melting. J. Geophys. Res. 100, 15581-15591.

Gardien, V., Lardeaux, J.M., Ledru, P., Allemand, P., Guillot, S., 1997. Metamorphism during late orogenic extension: insights from the French Variscan belt. Bull. Soc. Geol. Fr. 168, 271-286.

Gay, M., Peterlongo, J.M., Caen-Vachette, M., 1981. Age radiométrique des granites en massifs allongés et en feuillets minces syn-tectoniques dans les Monts du Lyonnais (Massif Central français). C. R. Acad. Sci. Paris 293, 993-996.

Huerta, A.D., Royden, L.H., Hodges, K.P., 1998. The thermal structure of collisional orogens as a response to accretion, erosion and radiogenic heating. J. Geophys. Res. 103, 15287-15302.

Lafon, J.M., Respaut, J.P., 1988. Géochronologie U-Pb et leucogranites varisques: cas des massifs de Grand-Rieu et de la Porcherie (Limousin), Massif Central français. Bull. Miner. III, 225-237.

Lagarde, J.L., Dallain, C., Ledru, P., Courrioux, G., 1994. Deformation localization with laterally expanding anatectic granites: 
hercynian granites of the Velay, French Massif Central. J. Struct. Geol. 16, 839-852.

Lardeaux, J.M., Ledru, P., Daniel, I., Duchène S. The variscan French Massif Central-a new addition to the ultra-high pressure metamorphic "club": exhumation processes and geodynamic consequences. Tectonophysics, in press.

Ledru, P., Autran, A., Santallier, D., 1994a. Lithostratigraphy of variscan terranes in the French Massif Central: a basic for paleogeographical reconstruction. In: Keppie, J.D. (Ed.), Pre-Mesozoic Geology in France and Related Areas. Springer-Verlag, pp. 276-288.

Ledru, P., Costa, S., Echtler, H., 1994b. Structure. In: Keppie, J.D. (Ed.), Pre-Mesozoic Geology in France and Related Areas. Springer-Verlag, pp. 305-323.

Leyreloup, A., 1973. Le socle profond en Velay d'après les enclaves remontées par les volcans néogènes-Son thermométamorphisme et sa lithologie - Granites et série charnockitique (Massif Central français), Thèse 3ème cycle, Univ. Nantes, 356 pp. (unpublished).

Macaudière, J., Barbey, P., Jabbori, J., Marignac, C., 1992. Le stade initial de fusion dans le développement des dômes anatectiques: le dôme du Velay (Massif Central français). C. R. Acad. Sci. Paris $315,1761-1767$.

Malavieille, J., Guihot, P., Costa, S., Lardeaux, J.M., Gardien, V., 1990. Collapse of the thickened Variscan crust in the French Massif Central: Mont Pilat extensional shear zone and St. Etienne upper Carboniferous basin. Tectonophysics 177, 139-149.

Matte, P., 1986. Tectonics and plate tectonics model for the variscan belt of Europe. Tectonophysics 126, 329-374.

Montel, J.M., 1985. Xénolithes peralumineux dans les dolérites du Peyron, en Velay (Massif Central français). Indications sur l'évolution de la croute profonde tardihercynienne. C. R. Acad. Sci. Paris 301, 615-620.

Montel, J.M., Abdelghaffar, R., 1993. Les granites tardi-migmatitiques du Velay (Massif Central): principales caractéristiques pétrographiques et géochimiques. Geol. Fr. 1, 15-28.

Montel, J.M., Weber, C., Barbey, P., Pichavant, M., 1986. Thermobarométrie du domaine anatectique du Velay (Massif Central français) et conditions de genèse des granites tardi-migmatitiques. C. R. Acad. Sci. Paris 302, 647-652.

Montel, J.M., Marignac, C., Barbey, P., Pichavant, M., 1992. Thermobarometry and granite genesis: the Hercynian low-P, high T Velay anatectic dome (French Massif Central). J. Metamorph. Geol. 10, 1-15.

Montel, J.M., Bouloton, J., Veschambre, M., Pellier, C., Ceret, K., 2001. Age des microgranites du Velay (Massif Central Français). Geol. Fr., in press.

Mougeot, R., Respaut, J.P., Ledru, P., Marignac, C., 1997. U-Pb chronology on accessory minerals of the Velay anatectic dome (French Massif Central). Eur. J. Mineral. 9, 141-156.

Patiño Douce, A.E., Johnston, A.D., 1990. Phase equilibria and melt productivity in the pelitic system: implications for the origin of peraluminous granitoids and aluminous granulites. Contrib. Mineral. Petrol. 107, 202-218.

Pin, C., Duthou, J.L., 1990. Sources of Hercynian granitoids from the French Massif Central: inferences from Nd isotopes and consequences for crustal evolution. Chem. Geol. 83, 281-296.

Pin, C., Peucat, J.J., 1986. Ages des épisodes de métamorphisme paléozoïque dans le Massif Central et le Massif Armoricain. Bull. Soc. Geol. Fr. 8, 461-469.

Pin, C., Vielzeuf, D., 1983. Granulites and related rocks in Variscan median Europe: a dualistic interpretation. Tectonophysics 93, 47-74.

Respaut, J.P., 1984. Géochronologie et géochimie isotopique $\mathrm{U}-\mathrm{Pb}$ de la minéralisation uranifère de la mine des Pierres Plantées (Lozère) et de son encaissant: le massif granitique de la Margeride. Thèse de 3ème cycle, Univ. Montpellier, 122 pp. (unpublished).

Rey, P., Burg, J.P., Casey, M., 1997. The Scandinavian Caledonides and their relationship to the Variscan belt. In: Burg, J.P., Ford, M. (Eds.), Orogeny Through Time. Geological Society Special Publication, vol. 121, pp. 179-200.

R'Kha Chaham, K., Couturié, J.P., Duthou, J.L., Fernandez, A., Vitel, G., 1990. L'orthogneiss oeillé de l'Arc de Fix: un nouveau témoin d'âge cambrien d'un magmatisme hyper alumineux dans le Massif Central français. C. R. Acad. Sci. Paris 311, $845-$ 850.

Roig, J.Y., Faure, M., 1995. La déformation du quartz dans un pluton syntectonique mis en place pendant l'extension Carbonifère supérieur du Massif Central français (le leucogranite de Chambles, Massif du Velay). C. R. Acad. Sci. Paris 321, 789-796.

Sabatier, H., 1991. Vaugnerites: special lamprophyre-derived mafic enclaves in some Hercynian granites from Western and Central Europe. In: Didier, J., Barbarin, B. (Eds.), Enclaves and Granite Petrology. Developments in Petrology, Elsevier, Amsterdam, vol. 13 , pp. $63-81$.

Thompson, A.B., Connolly, J.A.D., 1995. Melting of the continental crust: some thermal and petrological constraints on anatexis in continental collision zones and other tectonic settings. J. Geophys. Res. 100, 15565-15579.

Vanderhaeghe, O., Teyssier, C., 2001. Partial melting and flow of orogens. Tectonophysics this volume.

Vanderhaeghe, O., Burg, J.P., Teyssier, C., 1999. Exhumation of migmatites in two collapsed orogens: Canadian Cordillera and French Variscides. In: Ring, U., Brandon, M.T., Lister, G.S., Willett, S.D. (Eds.), Exhumation Processes: Normal Faulting, Ductile Flow and Erosion Geological Society, London, Special Publications, vol. 154, pp. 181-204.

Van der Molen, I., Paterson, M.S., 1979. Experimental deformation of partially-melted granite. Contrib. Miner. Petrol. 70, 299-318.

Vitel, G., 1985. La transition faciès granulite faciès amphibolite dans les enclaves basiques du Velay. C. R. Acad. Sci. Paris $300,407-412$.

Vitel, G., 1988. Le granite du Gouffre d'Enfer (Massif central français): Pétrologie d'un marqueur tectonique varisque. Bull. Soc. Geol. Fr. 6, 907-915.

Weisbrod, A., Pichavant, M., Marignac, C., Macaudière, J., Leroy, J., 1980. Relations structurales et chronologiques entre le magmatisme basique, les granitisations et l'évolution tectonométamorphique tardi-hercynienne dans les Cévennes médianes, Massif Central Français. C. R. Acad. Sci. Paris 291, 665-668.

Williamson, B.J., Downes, H., Thirlwall, M.F., 1992. The relationship between crustal magmatic underplating and granite genesis: an example from the Velay granite complex, Massif Central, France. Trans. R. Soc. Edinburgh: Earth Sci. 83, 235-245. 